\title{
4 CASE ONE: Legal Norm Injection Points in Indiana and Norway: the Selection of Particular Bodies
}

\subsection{Composition of the Indiana Legislature (1907)}

In this Chapter, I look at the composition of the Indiana legislature and the Norwegian Storting at the time these bodies passed their respective sterilization laws. One of my underlying assumptions in doing this examination is that the life experiences of these legislators and parliamentarians impacted their voting, although there is nothing so obvious as a strict correlation. Some legislators, who were from the upper classes, were involved in progressive movement politics just as some legislators, who were from middle and working classes, were involved in fighting against these reforms.

Of course, in 1907, all members of the state Legislature were men. But what were their values, their normative view of the "correct" way the state should proceed? In part, we can answer this through looking at such things as their occupations, ages, religion and life experiences that intersected with other institutions.

Between 1891 and 1929, the largest number of the 1,786 Indianan legislators was lawyers (533/29.7\%) followed by farmers (449/25.3\%), merchants/storekeepers (127/7.1\%), physicians or dentists (89/5.1\%), newspapermen/editor (55/3.0\%), bankers/financiers (49/2.7\%), businessman (47/2.6\%), realtors (43/2.5\%), teachers (42/2.4\%) and manufacturers (40/2.2\%). ${ }^{361}$ The occupation of the legislators made a difference as to who stood for election or not since mileage and a per diem were the only reimbursement to those elected. Between 1877 and 1925 both were fixed at $\$ 6$ per day and $\$ 5$ per week for each 25 miles traveled to and from Indianapolis. ${ }^{362}$ This, in turn, also had an effect on the turnover in the legislature. Generally, Senators stayed one year longer than Representatives. Between 1891 and 1929, 61.2\% of all representatives gave only one year of service, $28.4 \%$ gave two years, $6.5 \%$ gave three years and $2.0 \%$ gave four years. In the Senate, $6.9 \%$ gave one year of service, $74.7 \%$ two years, $1.6 \%$ three years, $11.6 \%$ four years and $2.6 \%$ six years. ${ }^{363}$

The mean age for senators between 1891 and 1929 was 48.2 years and for a representative was 48.8 years of age. ${ }^{364}$ About sixty percent had held public office at the

361 Justin E. Walsh, The Centennial History of the Indiana General Assembly (1816-1978) (Indianapolis: The Select Committee on the Centennial History of the Indiana General Assembly and The Indiana Historical Bureau, 1987), 708-709, Table 7: Occupations of Legislators. The remainder of legislators who accounted for more than $1.0 \%$ but less than 2.0\% were occupied as Artisan/Mechanic (18/1.0\%), Builder/contractor (21/1.2\%), Clergyman (18/1.0\%), Insurance (27/1.4\%), Railroad worker (23/1.2\%), salesman (23/1.2\%) and "other" (27/1.4\%). Of the 18 clergymen, 156 were from rural areas.

362 Ibid., 381.

363 Ibid., 706. Table 6: Tenure in the Indiana General Assembly.

364 Ibid., 400.

(cc)BY-NC-ND (c) 2014 Christine M. Hassenstab

This work is licensed under the Creative Commons Attribution-NonCommercial-NoDerivs 3.0 License. 
"township, city or county level" prior to their election to the Assembly. ${ }^{365}$ Generally, $86 \%$ of these who were elected to the House and $81.5 \%$ elected to the Senate had not seen military service although it "remained an asset" for those who did run and had served. ${ }^{366}$ Between 1901 and 1909, 58\% of the elected House members and 74\% of the Senate members had attended college. ${ }^{367}$ Between 1891 and 1929, most of those attending an Indianan college had attended Indiana University (12\%), Indiana State University (5.0\%), Purdue University (3.8\%), Vincennes University (0.6\%) and Ball State University $(0.3 \%) .{ }^{368}$ This appears to be a small percentage; however, only $72.7 \%$ of the legislators in this time period were actually born in Indiana, up from $34.1 \%$ in 1851-1889. While Indiana was becoming a "settled" state, in 1891-1929, many of the legislators were born in neighboring states such as Illinois (2.7\%), Ohio, (2.2\%), Kentucky (1.6\%) and Michigan (1.2\%); others were born in Pennsylvania (2.2\%), New York (1.5\%) and 2.1\% were born in Germany. ${ }^{369}$

The religious affiliation of elected legislators between 1891 and 1929 did not exactly follow the pattern of the religions' corresponding representation in the population in $1906 .{ }^{370}$ In the former period, most legislators were Methodists (419/23.4) followed by "Unknown” (349/19.5\%), Presbyterians (202/11.3\%), Disciples of Christ (193/10.9\%), “Not a Church Member” (129/7.2\%), Baptist (113/6.4\%), Roman Catholic (93/5.2\%), Lutheran (57/3.2\%), Society of Friends or Quakers (54/3.0\%), United Brethren (47/2.6\%) and Episcopalian (33/1.9\%). ${ }^{371}$ The 1906 survey would have indicated that the top three faiths of the representatives, in proportion to the general public, would have been Methodists, Roman Catholics and Church of the Brethren. But this is perhaps not significant since we do not know the parameters of both studies, i.e. which churches were included/excluded and the numbers for the 1891-1929 period of "Not a Church member" and "Unknown" are quite large. Nonetheless, the decline in Roman Catholic representatives in relation to their number in the general population may have been related to the fact that the German population might have been at that time largely an immigrant population and that the "Know nothing" movement, aimed specifically at Roman Catholic immigrants may have had some success. ${ }^{372}$

365 Ibid., 403.

366 Ibid., 401, 711, Table 8: Military Service of Legislators.

367 Ibid., 713, Table 9: College Attendance by Legislators.

368 Ibid., 713, Table 10: Attendance by Legislators at State Supported Institutions of Higher Learning. 369 Ibid., 702, Table 4: Birthplace of Legislators.

370 Ibid., 2.

371 Walsh, Centennial History, 721, Table 13: Religious Affiliations of Legislators.

372 During 1925, a bill directed at Roman Catholic nuns who taught in public schools was taken up and defeated - in the Assembly, i.e. the prohibition on the wearing of religious garb or symbols by teachers in public schools. While the Ku Klux Klan targeted African Americans during the night, they targeted other groups - especially Jews and Roman Catholics - during the day, with help of some of their Freemason members in what the KKK called the "Americanization" of Indiana. 
Finally, between 1910 and 1911, 45\% of House members and 54\% of Senate members were "known to be members" of the Freemasons; $47 \%$ of the legislature were also "known to be members." 373 Aside from the multitude of network resources that Freemasonry brought to the individual legislator, this is noteworthy because the Klu Klux Klan organization tried to utilize Freemasonry employing "every device to fasten itself upon the Masonic Craft...." 374 In summary, the "average" member of the General Assembly in 1907 was a lawyer, a Republican, 48.5 years of age, a first time member, and a Methodist. The House of Representatives for the State of Indiana began its regular session - its $65^{\text {th }}$ session - on Thursday, 10 January 1907.

What were the scientific discourses that circulated in this Legislature? This was, in part, answered by the above discussion of the macro-leveled eugenics movement in Indiana. But were those discussions the same at the meso-level? What meaning did the identity of "scientist" have and which members, associated with what institutional resources were involved in those discourses? The profession most associated with science was medicine and the Indianapolis News noted that, after the legislators themselves, the "first people to appear about the hotels" before the General Assembly had even finished breakfast "were a band of doctors, and they have been there all day since their arrival." 375

There were also doctors who were legislators. The Senate alone boasted four physicians, Dr. Richard R. McCain of Kentland, Dr. O.M. Keyes of Dana, Dr. Charles R. Lane of Ft. Wayne and Dr. McDowell of Sullivan and Knox County. The House had at least five doctor-legislators, Dr. A.W. Porter of Martin and Orange, Dr. Horace Read of Tipton and Hamilton, Dr. Scholl of Carroll, Howard and Miami, Dr. J. Frank Simison of Montgomery and Tippecanoe and Dr. John W. Vizard of Adams County. Of the entire legislature, these representatives were perceived as understanding scientific concepts and this perception is seen in the fact that doctors composed the majority of the Committee on Mental Health and Vital Statistics (CMHVS). It would be this committee that would initially evaluate the sterilization law in terms of whether or not it should proceed further through the legislative process. The eventual composition of the CMHVS would include Dr. Porter, Coble, Cox, Keller, Dr. Read, Dr. Scholl, Dr. Simison, Dr. Vizard, and Wade, with Read as the Chair of the Committee. ${ }^{376}$ (See Appendix C.)

373 Ibid., 722, Table 14: Freemasons in the Indiana General Assembly.

374 Ibid., 317. Quotation itself is from Dwight E. Smith, Goodly Heritage: One Hundred Years of Craft Freemasonry in Indiana (Franklin, Indiana, 1968), 224-225.

375 “Sounds Caught from General Legislative Hum.” Indianapolis News, January 7, 1907, 4.

376 Please see Appendix C for party affiliation and the other committees on which the individual CMHVS representative sat. The CMHVS representatives were from the following Counties: Porter (Martin and Orange), Keller (Marion), Cox (Ripley), Read (Hamilton and Tipton), Simison (Tippecanoe and Montgomery), Scholl (Miami, Carroll and Howard), Wade (Posey), Vizard (Adams), Coble (Dubois and Pike). 
Newspapers used different techniques to follow activities in the legislature. While the Star followed the Legislature with extensive daily reporting, the News also used a technique in which a reporter wrote a bi- or tri-weekly piece entitled "In Among the Legislators" authored by a reporter named Blodgett. His was a gadfly school of journalism where we learn - with some caveats - a bit more about the activities of these doctor-legislators than from the more direct reporting approach. For example, we learn that doctor-legislators stayed in touch with one another when Blodgett interviewed a former legislator and physician, Dr. Loren Gage of Grandview County. Gage had dropped in to "chat with old friends" as they gathered in one of the downtown hotels before the Legislature actually began. Gage had been a member of the House two years previously but did "not attempt to secure a renomination" after that term. ${ }^{377}$ This is also an example of where professional institutional affiliation granted access to legislators and facilitated an exchange of information. The concept of "networking" was not new to these men even though the term may be a more modern invention.

From Blodgett we also learn that Frank N. Wade of Posey, eventually one of the members of the CMHVS had arrived in Indianapolis on the $7^{\text {th }}$ of January. Wade said "he had no bills to present, but was interested in 'helping to kill some of the bad legislation that will be offered by other members'." ${ }^{378}$ Dr. Scholl eventually became the Chair of the CHMVS. Scholl had also served in the House in 1879 and when interviewed by reporter Blodgett, Scholl noted that there wasn't "much difference between then and now." The rules "were about the same" and the "way of doing business now is not much different" either. ${ }^{379}$ There was one major difference, however. In 1879, the Democrats had control of the House by six votes. This was exactly the same number of votes that, in 1907, gave the Republicans power in the same chamber.

Members of the CMHVS were busy from the start of the session and not only with science-related matters. For example, Rep. Dr. Scholl, during the same week as his interview with News reporter Blodgett, submitted an anti-trust bill and by 14 January, Rep. Dr. Read had submitted a bill concerning sales of personal property. On 15 January, Rep. Vizard submitted a bill on requiring electric companies to provide free meters to customers and Rep. Simison submitted a proposal to allow colleges to change the manner of electing trustees. ${ }^{380}$ Yet another member of the CMHVS, Senator Lincoln A. Cox of Marion County, proposed that police pensions be equalized but in no case should they be set at less than $\$ 10$ or more than $\$ 50$ per month. ${ }^{381}$

377 "Legislators Arrive Ready for Action. Fights for Appointive Positions Tame Compared With Those of Previous Years. Party Caucuses Tomorrow. Selection of Branch for Speakership Now Seems Assured.” Indianapolis Star, January 8, 1907, 3.

378 Ibid.

379 Ibid.

380 Indianapolis News, January 15, 1907, 3.

381 Indianapolis Star, January 16, 1907, 3. 
The Editor of the Star usually reserved the extreme left-hand column on the editorial page for what he considered humorous comments and gossip. He was also familiar with the doctor-legislators and it was not long before we find a first reference in this column to George T. Porter, a member of the CMHVS. Porter was quoted as reminding the Star that it was his father, the late Governor Albert G. Porter (1824-1897), "who first urged the appointment of women to a part in the official management of State institutions." ${ }^{382}$ In short, these doctor-legislators were involved in all types of matters, not only those scientific or medical.

The Senate also had members who were doctors and one, Sen. Dr. McCain, gave his first speech on 14 February. According to reporter Blodgett, the speech was not long but it was "effective" since "the Kentland doctor voted just as he talked - and that is more than some of the members of the General Assembly do." 383 Procedurally, we know that all bills had to pass through committees in both the House and the Senate. In the Senate, those bills that the House had approved and that dealt with public health needed to come before its Committee on Public Health; Sen. Dr. McCain, from Jasper, Newton, and White Counties was the chairman of this committee. During the 1907 Legislative session, McCain would spend a great deal of time dealing with the sanitary bottle bill, where he and Board of Health Secretary, Dr. Hurty would clash. ${ }^{384}$ There is no mention of McCain and his Committee considering the sterilization law.

The final appointments to various other committees of the CMHVS members are included in Appendix C. From this, we can see that Scholl was on the most committees although some of his committee appointments were presumably not as time consuming as others, e.g. comparing the Soldiers Monument Committee and the Ways and Means (Budget) Committee. At least two CMHVS members - Cox and Wade - were on the committees that dealt with prisons and reformatory and so contact with Dr. Sharp and Supt. Whittaker was possible. Scholl was on the State Library Committee and as such, had contact with the State Librarian, Demarchus C. Brown, who was in the process of translating and distributing literature to the legislature from Germany on prison reform; Brown read German and was interested in progressive topics and how reforms were being made in Germany. ${ }^{385}$ In summary, it appears as if Porter, Read and

382 Indianapolis Star, January 15, 1907, 8.

383 "Right in Among Legislators." Indianapolis News, February 15, 1907, 4.

384 Indianapolis Star, January 30, 1907, 8. Hurty was against the bill.

385 Indianapolis Star, May 26, 1907, 28. Demarchus C. Brown was busy translating Professor Berthold Freudenthal's address before the International Penological Society in Germany on Sept. 6, 1906. (Ibid.) Although this might not be a remarkable event, the translation was to be used by the Board of State Charities, and it appears, would be passed around to state officials who might be interested. At the time, Freudenthal was a law professor at Frankfurt University who would become one of the architects of Weimar Germany's penal system. The title of Freudenthal's address was "American Criminology" and a substantial portion of the translation was printed in the Star. Professor Freudenthal was not entirely enthusiastic about American prisons and reformatories, but, by the same token, did 
Simison were the most powerful in CMHVS, next to Scholl. Also, just as today, various personalities and the interest groups they represented had access to members of the CMHVS.

Set alongside these legislative "big but slow-moving [micro-social] processes" is the fact of institutional processes. ${ }^{386}$ Analysts who do not look at these larger processes are "prone to a number of serious mistakes." ${ }^{387}$ As Pierson says:

They are particularly likely to miss the role of many "sociological" variables, like demography, literacy, or technology. Their explanations may focus on triggering or precipitating actors rather than more fundamental structural causes. It can get worse. By truncating an analysis of process unfolding over an extended period of time, analysts can easily end up inverting causal relationships. $^{388}$

An example of how sociological variables can be missed is seen in David Carpenter's The Forging of Bureaucratic Autonomy where he criticizes the then current (2001) "agent-principal" theory which is based on a cross-sectional approach, in favor of an approach wherein "ambitious and entrepreneurial bureaucrats were able to enhance their reputations for innovativeness and competence and develop strong networks of support among a range of social actors." ${ }^{389}$ At that time, what looked like Congressional dominance on the outside was, in fact, Congress asking "for what the bureaucrats

not say that Germany had a better system. Citing statistics, he noted that the "picture of American criminal conditions is not spotless." (Ibid.) The crux of the problems in America was "American officialdom" where "the men who belong to the party in power, but in point of fact incompetent men, are frequently given positions in the penal institutions [and c]apable men have been removed from their places." Freudenthal also noted a theoretical debate in American criminology that would continue into the present day. He said:

In America retributive and reformatory punishment have been in conflict, and even yet there are quite often flashes of lightening in the penological heavens of the Union.

Freudenthal presented for his audience a picture of the various stages of the reformatory that should be "built up like classes in school. The higher the class, the nearer the approach to full freedom." He also noted that religion played a role in the reformatory in America as "a means of education of the highest rank...." (Ibid.) The Atlantic Ocean may have been "eugenic" but it was also "progressive."

386 The vocabulary from social movements' theory and the vocabulary from Sewell are not always the same. Social movement theorists talk about "institutions" and Sewell writes about "structures." For my purposes, I conceive of "institutions" as part of "structures" in Sewels triad of "structures, schemas and resources."

387 Paul Pierson, “The Study of Policy Development” in The Journal of Policy History, 17 (2005), 42. 388 Ibid.

389 Ibid. See Daniel P. Carpenter, The Forging of Bureaucratic Autonomy: Reputations, Networks, and Policy Innovation in Executive Agencies, 1862-1928 (Princeton, New Jersey: Princeton Univeresity Press, 2001). 
[already] wanted." 390 A particular moment in time, a moment of choice, should be to be seen as part of a cultural, social and political process.

An example of how these larger institutional processes can be overlooked is found in the work of four Indianans. Nowhere in the short, official legislative history of the first sterilization law in the world can we find these four names - Dr. John N. Hurty, Dr. Henry C. Sharp, Dr. Amos W. Butler or Oscar McCullough. These four men were individuals but are also representations of the structures, schemas and resources available to the "progressive" social movement as well as to the eugenics movement in 1907 in Indiana. ${ }^{391}$ As noted above in Chapter 3, these two movements often articulated, forming framing bridges with one another as well as with numerous other structures generated by the progressive movement such as the suffragette movement and various religious faiths. As such, they represent the following bridges; medical-legislative structure (Hurty), the progressive-medical structure (Sharp), the progressive-institutional structure (Butler) and the progressive-religious structure (McCullough).

In 1907, Dr. Hurty was the Vice President of the State Medical Association and secretary of the Indiana State Board of Health (ISBOH). The power generated by medical institutions is matched only by government itself and religion and during this period, the medical institution was actively involved in helping to frame issues in collective action with these institutions. Medicine played a hegemonic role in defining and in the amount of flexibility and rigidity accorded the terms "healthy" and "unhealthy." What the ISBOH and its members said possessed a great deal of resonance in the public. Their words had an experiential commensurability since they coincided with the values that had meaning in the lives of their patients. ${ }^{392}$

Dr. Hurty was the "father" of what would become known as the field of "public health" in Indiana. He was one of the more active figures that the Star would report

\section{Ibid.}

391 Paul Pierson argues that, to look at precipitating actors, without looking at large structural changes, one can mistakenly attribute causality. (Paul Pierson, "The Study of Policy Development, 42. Note 568.) . As he writes:

They are particularly likely to miss the role of many "sociological” variables, like demography, literacy, or technology. Their explanations may forcus on triggering or precipitating actors rather than more fundamental structural causes. It can get worse. By truncating an analysis of process unfolding over an extended period of time, analysts can easily end up inverting causal relationships.

(Ibid.) My work sidesteps this criticism since I try to evaluate institutional changes in addition to the agents involved in the institutions. I also do not claim to prove causation per se but rather, important factors in the development of phenomenon.

392 Please see, Robert D. Benford and David A. Snow, Framing Processes and Social Movements, 618-622. Salience and experiential commensurability are the criteria the authors use for exploring how successful framing is is social movements. 
on throughout the legislative session. ${ }^{393}$ For example, on 9 January 1907, the Star reported that, at the annual convention of the Tristate Medical Association, at the "earnest" request of Dr. Hurty, the group had endorsed the proposal for a State hospital to treat consumption (tuberculosis). ${ }^{394}$

One legitimating activity of the ISBOH was the collection of facts and figures. It had compiled figures on the nature and spread of epidemics beginning in 1900. In 1907, they published statistics which showed a "remarkable falling off" of epidemics. In 1900, the number of people affected by typhoid fever was 1,329, diphtheria 687 and scarlet fever, 141. By 1906 those numbers had dipped to 846, 341 and 97 respectively. ${ }^{395}$ Other public health measures that now seem obvious in hindsight were proposed during the session. The so-called Pearson Bill gave the State Board of Health the power to revoke a physician's license should he not comply, along with householders and others, to report deaths, births, infectious diseases and other information. Senator Pearson's bill also gave the ISBOH - and Hurty - the ability to discharge any local health officer who refused to make proper reports. Even though the Senate thought the bill "too drastic", since it might discharge some citizen who did not know the difference between "infectious" and "contagious" diseases, it was passed, 26 to 19.396

Dr. Henry C. Sharp was employed as a physician at the Indiana Reformatory in Jeffersonville. As "early as 1899" he had "begun experimenting with the sterilization of prisoners" but "on a voluntary basis" and extra-judicial basis. ${ }^{397}$ I will examine his role in detail below.

Another institutional force was the Indiana Board of State Charities (IBOSC). It secretary was Amos W. Butler, who, on 1 May, reported that all of the State hospitals for the insane were full or overcrowded as was the School for the Feeble-Minded Youth and School for the Deaf. The Reformatory, the State Prison and the Sailors' Home were overcrowded as well. The Epileptic Village in Newcastle would be ready soon and new buildings at the Reformatory and the Feeble-Minded School would decrease overcrowding. The IBOSC also criticized the Marion County Jail. It normally had a capacity of 35. At their last visit, the Jail had 93 inmates, including 35 in the basement that had space and equipment for only $10 .{ }^{398}$ While Butler was concerned about this turn

393 "Favor State Hospital. Would Fight White Plague. Northern Tristate Medical Association Favors Dr. Hurty's Plan to Care for Tuberculosis Patients and Fight Spread of the Disease.” Indianapolis Star, January 9, 1907, 8.

394 Ibid.

395 Indianapolis Sunday Star, February 3, 1907, 1.

396 Indianapolis Morning Star, February 16, 1907, 4.

397 Phillips, Indiana in Transition, 492. Cited by Gugliotta, Footnote 416 at p. 376, where we also learn that Dr. A.J. Oschner, chief surgeon at St. Mary's Hospital in Chicago and who was later a professor of clinical surgery at the University of Illinois at Chicago, began performing vasectomies in 1887, two years before Sharp. The records from the reformatory that included Sharp's files were burned in a fire. 398 Indianapolis News, May 1, 1907, 4. 
of events, his solution was to support the work of Dr. Sharp. At a meeting of township trustees in either December, 1906 or January 1907, Butler said that "in time the State would enact legislation to regulate the birth of children in families of the dependent poor and stated also that method was now in use in the penal institutions of the State by which inmates were deprived of the power of reproduction." ${ }^{399}$ Here we can see the institutional force of the IBOSC as represented by Butler already advocating for the sterilization law which would become a reality in a mere three months.

Oscar McCullough was leader of the Plymouth Congregational Church in Indianapolis. He also acted as a liaison with business leaders and, twenty-seven years before the legislation in question was passed, founded the Indianapolis Charity Organization Society (ICOS). ${ }^{400}$ McCullough represents the socio-religious bridge where religious leaders advocated for legislation that they believed would advance Christian ideals and these ideals were often subsumed into the idea of progress based on positive eugenic ideas. Although a religious leader, McCullough had written a book entitled Tribe of Ishmael: A Study in Social Degradation in $1881 .^{401}$ He had used records from a group of families in the Indianapolis area to prove that features of degradation were inherited. ${ }^{402}$

McCullough and his ICOS regularly disseminated "healthy-living information." For example, the Star noted a lecture by one Dr. U.G. Weatherly, Professor of Economics and Social Science at Indiana University, entitled "The Physical Basis of Society." The lecture was produced under the auspices of the ICOS as part of a two-month long lecture series on social problems. Weatherly himself took a middle ground on the "correct" size of families saying that he was not in agreement with either side of the issue. He did say that "neither the advocates of excessively large families nor those of families so small as to lead to race suicide...."403

The varied resources that were available to McCullough, as well as the other three men, were far-reaching. For example, Linton A. Cox - also a member of the CMHVS was active on welfare issues in the 1907 legislative session from its beginning. On 17 January he proposed legislation on behalf of the Indianapolis Charity Organization Society making abandonment or neglect of a child a criminal felony. ${ }^{404}$ The Star report gives an indication of the ICOSI's motivation and lobbying ability saying that it "confronts many pitiable cases in which children have been deserted by parents

399 Indianapolis Star, (Indianapolis), January 9, 1907, 8.

400 Ruth Hutchinson Crocker, "Making Charities Modern: Business and the Reform of Charities in Indianapolis, 1879-1930" in Business and Economic History, Second Series, Vol. 12, (1983), 161.

401 Oscar McCullough, Tribe of Ishmael: A Study of Social Degradation (Indianapolis, 1881).

402 Please see, http://www.hmdb.org/marker.asp?marker=1829, accessed May 15, 2009.

403 “Advocates Small Families. Dr. Weatherly Delivers First of a Series of Lectures.” Indianapolis Star, January 15, 1907, 10.

404 "To Protect Children Strikes At Salaries. Child Desertion A Felony. Through Senator Cox Indianapolis Charity Organization Introduces Stringent Measures.” Indianapolis Star, January 17, 1907, 4. 
and it will work hard for the passage of the bill." 405 The proposed bill provided for imprisonment in either the State Prison or Reformatory for a term of 1 to 3 years or in the county jail or workhouse for no less than 3 months and nor more than 1 year of either or both parents. ${ }^{406}$

In 1907, these four men, and the institutional structures and power that they represented, demonstrate the intersection of agents from strong organizational structures in Indiana, all with numerous resources. Their schemas, or social rules and procedures, were transposable across a "wide range of circumstances" that were not entirely predictable "outside of the context in which they are initially learned." ${ }^{407}$ When their schemas were set in motion, they produced "unpredictable qualities and quantities of resources." ${ }^{408}$

\subsection{Legislative Discourses: Legislating against Sin}

As I have previously noted, between 1890 and 1930, Indiana shifted from a ruralbased society to an industrialized state. This shift, however, was not reflected in the Legislature, which remained a "bastion" of rural interests. ${ }^{409}$ As Walsh points out, "partisan politics, not population shifts, dictated apportionments with rural ascendancy the one constant whether Democrats and Republicans did the dictating." ${ }^{410}$ As a result, "appeals to such old-fashioned virtues as hard work, clean living, and tem-

\footnotetext{
405 Ibid.

406 We are told of at least some of the elements of the crime, i.e. the child in question must be less than 16 and the parent must be able to care for the child - but not doing so. If the convicted parent gave a "satisfactory bond" that the child would be cared for, the sentence could be suspended. As today, the "suspended" sentence was suspended only as long as the terms of the suspension were complied with. Should the convicted parent fail to meet the terms, s/he would then be in the same position as before the suspension, i.e. facing imprisonment, fines, etc.

407 Sewell, Logics, 140-41.

408 Ibid.

409 Walsh, Centennial History, 290.

410 Reapportionment of the state into House and Senate districts was a more or less continuous concern of the legislature between, 1816 and 1921 with only a short break for the Civil War. House and Senate Districts were re-mapped in 1821, 1823, 1826, 1829, 1831, 1834, 1836, 1841, 1846, 1851, 1857, 1867, 1872, 1879, 1885, 1891, 1893, 1897, 1905, 1915, 1921, 1963, 1965,1972 (Appendix B, Walsh). Federal Congressional Districts were redrawn in 1822, 1824, 1833, 1843, 1852, 1867, 1872, 1879, 1885, 1891, 1895, 1901, 1911, 1931, 1941, 1965, 1968 and 1972 (Appendix C, Walsh). Re-mapping was initially done to accommodate the push westward but later to accommodate political goals of whichever party was in power. In 1962, in the United States Supreme Court case of Baker v. Carr, 369 US 186 (1962), 82 SCt 691, 7 LEd2d 663, the Supreme Court required that the "one man, one vote" principle meant that each person's vote had to be equally weighted. This took into account growing urban populations and numerous states underwent legislative reapportionment.
} 
perance dominated legislative deliberations." ${ }^{411}$ Many types of leisure activity were open for review by the General Assembly including horse racing, baseball - especially if played on the Sunday - boxing, and theatrical performances. Keeping the Sabbath holy, art free of any "obscenity" and Indiana's sober were some of the major concerns of the legislators. In other words, it became a "matter of habit" to "legislate against sin." ${ }^{412}$

Harold Feighter was a reporter for the Indianapolis News and covered every General Assembly about 14 years after the sterilization law was passed - from 1921 to 1933. During that time, he noted that what dominated state government was the "Ku Klux Klan, the Anti-Saloon League, and the Horse Thief Detection Association” and that each had a "divine mission." ${ }^{413}$ These missions were to

purify politics, ...stop drinking by means of force and fear of damnation, and...to safeguard chastity in lovers' lanes. Collectively, these forces of righteousness swallowed the Republican Party and caponized [castrated] the Democrats. ${ }^{414}$

As the Republicans were in a majority in the legislature during this period, they according to Feighter - could be held responsible for the governmental "excesses" imposed by attempts at social purification. ${ }^{415}$ Although Freighter describes a period after the sterilization law was passed, his remarks would also seem to apply to 1907, especially in light of the social history outlined below.

On 15 January 1907, the Editor of the Indianapolis Star wrote about “Temperance Legislation”, one of Governor Hanley's favorite subjects. Buried in his editorial page we find a reference to "temperance laws that are effective" standing in direct opposition to those that do not work. For effective temperance laws, he turns to Norway. He wrote:

Norway, for example, has in a few years been changed from a nation of drunkards to a nation of sober people by simple law. Under it a drunken man is imprisoned until sober. He is then cleaned up. If his clothing is torn it is mended or he is furnished with new clothing. He is then required to tell where he got his last drink, and is kept in prison until he does tell. The person who sold that drink is then required to pay all expense of incarceration and rehabilitation together with any damage done by the drunken man..$^{416}$

411 Ibid.

412 Ibid., 306.

413 Walsh, Centennial History, 309. The "Horse Thief Detective Association" is a reference to a detective agency closely linked to the Klu Klux Klan.

414 Ibid.

415 Ibid.

416 Indianapolis Star, January 15, 1907, 8. 
This indicates that Indiana was indeed aware of the wider world and that the Editor was not averse to using the conduct of other nations as an argument for change. It also supports the practice, seen in legislation in general, of referring to laws in other countries that seem to support the specific law being discussed. ${ }^{417}$ Whatever else changed in Indiana and Norway between 1907 and 1934, the one constant that remained was that at both times and in both countries, "liquor" was the subject of a social movement that was framed in terms of sin and moral weakness. ${ }^{418}$

In addition to doctors, "well dressed men" who looked familiar and came to Indianapolis every time the Assembly met were also the first to appear in the capital. These men, who "like to drop in and pick up a little perfumery money" were lobbyists, "Hessians of the third House", whom reporter Blodgett described as being "without influence, but with a nerve as strong as corrosive sublimate, and an ability to "cop the dough' under any and all circumstances." ${ }^{419}$ Unethical, these men did not care where the money came from, as long as they were paid, according to Blodgett.

The session began with a roll call after which Rep. Hanna of Hendricks County submitted the name of Rep. Emmett F. Branch, Republican from Morgan County, for nomination as Speaker of the House. Branch's opponent was Rep. Thomas J. Honan of Jackson County, nominated by Rep. Behymer of Madison County. By a vote of 53-47, Rep. Branch was declared the Speaker-elect, thus having a "life and death power over bills." ${ }^{420}$ In total, this regular session lasted from 10 January 1907 to 11 March 1907 (61 days) and, in addition, a special session was called, lasting from 18-30 September 1907 (13 days).

At 2:00 P.M., Governor Hanley knocked on the doors of the House and was escorted to the podium by four selected men. Hanley then proceeded to give his state of the State address, which he began by noting, "Monetary conditions are at their best." ${ }^{421}$ He continued, saying:

Labor, agriculture, manufacturing, mining and commerce have touched and passed high tide and the ebb is not yet begun... During the last year there was no failure of any financial institution within the State. Taken all in all, conditions are indeed unusual. They present a problem

417 Later in 1934, Norwegian Parliament Representative Bjørnson mentions the laws of Germany as examples of effective and useful legislation.

418 It would not be until the advent of Alcoholics Anonymous that alcoholism would be framed as a health issue and not a moral issue.

419 "Whiffs from the Legislative Spice Box." Indianapolis News, January 8, 1907, 4. Corrosive sublimate is a reference to acid.

420 Ibid., 373. This power was not seriously challenged until sometime after 1929. The conflict over Branch's election was intense.

421 Journal of the House of Representatives of the State of Indiana, Sixty-Fifth Session of the General Assembly, Commencing January 11, 1907, Regular Session, Vol. I (Indianapolis: Wm. B. Burford, Contractor for State Printing and Binding, 1907), 17. 
unlike that which usually confronts state legislatures... The challenge is not "Can we create?" but "Can we administer?" 422

When Hanley reached the subject of Indiana's state charitable institutions, he specifically mentioned that, although they were run in an efficient and economical manner, that there was room for improvement. His remarks about the State Prison system began with the fact that the labor contracts of Prison employees were due to expire in 1910. Hanley did not mention anything regarding the medical facilities of the State Prison, or the need for the sterilization of "confirmed criminals, idiots, imbeciles, and rapists." 423

In 1907, tuberculosis, referred to as the "white plague”, was a continuing medical problem in the United States and the state of Indiana. When addressing this issue in his speech, Hanley referred to a resolution passed on March 5, 1905 at the $64^{\text {th }}$ General Session, which authorized a commission of 5 persons, 2 Representatives, 2 Senators and one "a practicing physician of prominence in the State", to investigate the establishment of a TB Hospital in Indiana. ${ }^{424}$ While this might be interesting information per se, the point of its inclusion here is that there was no such equivalent committee formed with regard to the "medical" issue of sterilization at the state prison. Why was tuberculosis a scientific issue worthy of study and sterilization not? I would suggest that tuberculosis affected the bodies of normal citizens - both male and female some of whom were unable to care for their medical needs and who needed to be separated from the community at large. The bodies of criminals, on the other hand, were in another category, a "degenerate" category. The two categories of "normal" and "degenerate" did not allow the normal citizen to see that criminality could attach itself to his or her family through any number of a series of events, or, if it had, this was a matter kept secret. Therefore, since criminality was seen as only a socially unacceptable category, and not as a medical issue, there was no interest in an investigation by an expert committee.

At the conclusion of his speech, Hanley used a phrase, which after a century, has now taken on a life of its own. He said:

Special interests, individual and corporate, are wont to exercise undue influence upon all legislation relating to any matter of concern to them. They fill legislative chambers and the approaches thereto...Their attitude [is expressed] with exactness in the couplet, Whose bread I eat, His song I sing.

Such persons are not safe counselors. They are the enemies of the people's interests. Their very presence is inimical to the public welfare. Human rights - the rights of the individual citizen, or the rights of [the] body of the people - are not safe where legislation can be procured or def-

422 Ibid.

423 Statute, Chapter 215 of the Laws of Indiana. Please see below for entire text.

424 Journal of the House of Representatives, 65. 
eated or government administered through the corrupt and demoralizing influence of the paid [acting for] organized wealth and greed. ${ }^{425}$

Human rights were obviously important enough to be included as rhetorical ideology in this speech and it is especially ironic that Hanley should make mention of it in the very same sentence as the concept of the body politic. This serves to underscore the change in norms over time as well as the idea that the individual body could be abstracted from the corporate body by virtue of a number of classifications. ${ }^{426}$

An individual body within the "body of people" was a very "porous" category at this time, as evidenced by the fact that the law could be extended across a wide spectrum of bodies in a rather short period of time. The "feeble-minded" had already been a legislated category in 1901 when women, ages 16-45, who were "unsupervised" could be made legal wards of the state in order to prevent them from reproducing. ${ }^{427}$ And, on 5 March 1905, Governor Hanley approved a law prohibiting "imbeciles, epileptics and those of unsound minds" from obtaining a marriage license. ${ }^{428}$ The law was then further extended to criminals who were degenerate.

The 1907 Indiana sterilization bill was not the first attempt to pass such a law in the state of Indiana or indeed, within the United States proper. Angela Gugliotta writes that two years earlier in 1905 under the Republican administration of Governor Winfield Taylor Durbin (s. 1901-1905), a sterilization bill in Indiana had been introduced but "died in committee." ${ }^{429}$ Nonetheless, the 1907 Indiana sterilization bill began life - again - as House Bill No. $364 .{ }^{430}$ The sole sponsor of the bill was Rep. Dr.

425 Journal of the House of Representatives, 68 (Emphasis mine.)

426 Indianapolis Star, January 25, 1907, 3.

427 Laws of Indiana, 1901, 156-59.

428 Laws of Indiana, 1905, 215-16.

429 Gugliotta, Sharp and His Little Knife, p. 386-87. Note 330. This was after Pennsylvania Governor Samuel W. Pennypacker (1903-1907) vetoed Pennsylvania Senate Bill No. 35 "An Act for the prevention of idiocy" and sent it back to the legislature saying, tongue-in-cheek, that:

If idiocy could be prevented by an act of assembly, we may be quite sure that such an act would have long been passed and approved in this state, and that such laws would have been enacted in all civilized countries.

(Tony Platt, "The Frightening Agenda of the American Eugenics Movement” http://hnn.us/articles/1551.html, last accessed 15 March 2006. Within seven years, from 1907 to 1914, twelve states had passed sterilization laws in one form or another.

430 The procedure in a bi-camarel legislature, such as that of Indiana at this time, was similar to today's practice of creating law. Today, under the Constitution of Indiana, a bill may be introduced in either the House or the Senate of the General Assembly and may become "engrossed" (approved) there. The approval process includes a "first reading" in the chamber where it was introduced whereupon it may be sent to the appropriate committee to review. If it is not sent to a committee, the bill "dies." The committee review process may include public hearings. If the committee schedules no hearings, the bill again dies. A vote is taken after the committee review hearing and, if it receives a 
Horace D. Read. ${ }^{431}$ Read introduced the bill 17 days after the session began, and it had its first reading on 27 January $1907 .^{432}$

After the first reading, the bill was sent to the House Committee on Medicine, Health and Vital Statistics When finally enacted into law the bill read as follows:

\begin{abstract}
AN ACT to prevent the procreation of confirmed criminals, idiots, imbeciles and rapists: Providing that superintendents or boards of managers of institutions where such persons are confined shall have the authority and are empowered to appoint a committee of experts. Consisting of two physicians, to examine into the mental condition of such inmates. WHEREAS, heredity plays a most important part in the transmission of crime, idiocy, and imbecility:
\end{abstract}

THEREFORE, BE IT ENACTED BY THE GENERAL ASSEMBLY OF THE STATE OF INDIANA, that on and after the passage of this act it shall be compulsory for each and every institution in the state, entrusted with the care of confirmed criminals, idiots, rapists and imbeciles, to appoint upon its staff, in addition to the regular institutional physician, two (2) skilled surgeons of recognized ability, whose duty it shall be, in conjunction with the chief physician and board of experts and the board of managers. If in the judgment of this committee of experts procreation is inad-

simple majority, it is returned to the chamber where it came from where it receives a "second reading." If it does not receive a second reading, the bill again dies. If it does have a second reading, amendments may be proposed and can be added by a simple majority vote. The full chamber then votes on the bill and with the approval of a simple majority it advances to a "third reading." If it does not receive a third reading, it may again die. After a third reading, a vote is taken on amendments where, unlike after the second reading, a 2/3 majority is required for passage of the amendments. If the amendments are approved at this point, it is sent to the entire chamber where a simple majority will ensure that the vote then is sent to the other chamber. If that chamber fails or refuses to act on the bill, it again dies.

In the second chamber the same process as occurred in the first chamber is repeated, with the same possibilities of failure. If the other chamber approves the bill, it is sent to the chamber of origin where that body reviews the amendments, if any, that the other chamber has made. The chamber of origin may then do nothing, whereupon the bill dies, it may approve the amendment made or it may send the bill to the Governor for her signature. If the chamber of origin does not approve the amendments made in the other chamber, the bill is referred to a "conference committee." This committee is composed of two members from both major political parties and the four attempt to reconcile problems; if this cannot be done, the bill dies. If an agreement is reached, the bill is returned to both chambers where it must be approved before finally being sent to the Governor for signature. The bill does not automatically become law however, as the Governor may veto it, sign it into law or simply not sign it and allow it to become law. If the Governor vetoes the bill it goes back to both chambers and, in order to "over-ride" the Governors veto, a simple majority of at least 26 Senators and 51 House members must vote for the bill. Please see http://www.state.in.us/statehouse/tour/Billtolaw.pdf, accessed 10 March 10, 2007.

431 Read was a Joint Representative from the two counties of Hamilton and Tipton. The other representative from Hamilton County was Henry M. Caylor and there was no other representative from Tipton County. The issue of "Joint Representatives" was addressed by the United States Supreme Court in the reapportionment case of Baker v. Carr, 369 U.S. 186 (1962), mentioned above in fn. 587.

432 Journal of the House of Representatives, State of Indiana, during the Sixty-Fifth Session General Assembly, Commencing Thursday, January 11, 1907, Regular Session, Volume II (Wm. B. Burford: Contractor for State Printing and Binding, 1907), 302, 367. 
visable, and there is no probability of improvement of the mental and physical condition of the inmate, it shall be lawful for the surgeons to perform such operation for the prevention of procreation as shall be decided safest and most effective. But this operation shall not be performed except in cases that have been pronounced unimproveable. Provided that in no case the consultation fee be more than three dollars to each expert, to be paid out of the funds appropriated for the maintenance of such institution. ${ }^{433}$

The assumptions in this legislation are numerous and, at this point, I will only mention the scientific assumption, i.e. that "heredity plays a most important part in the transmission of crime, idiocy, and imbecility" and that beneficial science will correct the social situation. ${ }^{434}$ Most members of the legislature perceived this as a correct scientific statement given how they voted.

Problems with statutory drafting were and are fairly obvious. Does the adjective "confirmed" relate only to criminals or also to the other 3 categories. Also, how is "confirmed" defined and what is the standard of proof for determining "confirmed"? Appellate arguments regarding construction have been made, and won, with these types of questions.

At the end of any legislative session, some policy measures were lost in rush to end the session. In 1923, the Indianapolis Star finally complained that the "good measures are lost in the final scramble and occasionally vicious legislation slips through." 435 And this was also true in 1907. The sterilization law was passed on 6 March, only

433 Document URL: http://www.kobescent.com/eugenics/statute.html accessed 3 December 3, 2007. 434 During the first week of March, the Senate passed the sterilization bill into law. The Star reported on the bill in its headline as a "modern operation" that had already been employed at the State Reformatory thus legitimating it as "modern", i.e. a means to "progress" and as a fait accompli to a procedure already well in place. (Indianapolis Star, 7 March 1907, p. 10. "Surgeons to Deal With Criminals. Bill Passes the Senate Authorizing Modern Operations to be Performed. Tried at the Reformatory. Supt. Whittaker Urged Enactment of Such a Law.") Rep. Read's House bill had passed the Senate on 6 March "with few votes being recorded against it." Read's personal interest in the subject was reported to have originated in materials that were given to him by Superintendent William H. Whittaker of the Indianan Reformatory, whom we have encountered above, and where Dr. H. Sharp was already performing extra-judicial vasectomies; these were reportedly performed only upon request. Both Whittaker and Sharp had been "very active in urging upon the members of the Legislature the importance of passing the bill." Angela Gugliotta writes that Whittaker actually was the author of the language in Read's proposed bill. (Gugliotta, Sharp and His Little Knife, 387. Note 330.)

435 Walsh, Centennial History, p. 383-384. Between 1900 and 1930 state spending in Indiana doubled and spending at the local level quadrupled. This meant that property taxes in 1930 were 7 times higher than in 1900. Since property valuations could not keep pace with actual spending, nearly every legislative session voted to raise taxes. Inheritance taxes, vessel tonnage taxes, gasoline taxes and the like were also passed since property taxes were not able to generate an adequate tax base. Budget items were generally the last order of business on the last day of the session and "frequently did not pass before the last minutes on the last day" thus requiring legislators to come back in the Fall for a special session. Walsh at 388-389. 
5 days before the legislature ended in its mad dash to sine die. ${ }^{436}$ Also, in 1907 , the "number and title of bills bearing a lawmaker's name" determined the continuation of a political career. Aside from the legislator himself, constituents also demanded certain legislation, “as a matter of courtesy.” Thirdly, fraternal or professional organization such as the Freemasons or the state Medical Association lobbied for legislation. Private interests and corporations who hired professional lobbyists joined these groups as did state administrative officers and committees or commissions who were under the authority of the state legislature. ${ }^{437}$ In virtually every session a bill was considered that "forbade lobbyists to communicate with members on the floor" but, such resolutions were "never effective, however, as the press was filled with accounts of lobbyists jamming the floors of both houses during every session." 438 All these factors impacted the atmosphere in which this law was passed.

These factors have added significance since all that we have in print of the proceedings of the Legislature is in Volume II of the Indiana House Journal where one can read the formal compiled history of Bill $364 .{ }^{439}$ After being "Read first time" and then "referred to Committee on Medicine, Health and Vital Statistics", it was next "Withdrawn" but then "Reported back favorably." ${ }^{440}$ Somewhat further on in the same Journal we read, "By unanimous consent House bill No. 364 was withdrawn from the files." ${ }^{441}$ Finally, we read that Rep. Read submitted the report of Medicine, Health and Vital Statistics as a recommendation that the bill be passed..$^{442}$ The bill was then read for the second time in the House and was ordered to be engrossed (approved) ${ }^{443}$ It was read a third time in the House and then passed by a majority vote of 59-22. It was then referred to the Senate and passed by a majority vote of 28-16. Later House Bill

436 "Sine die" is a Latin phrase, literally meaning "without a day", i.e. without a day to return to the work of the legislature.

437 Walsh, Centennial History, 384.

438 Ibid., 426.

439 Private e-mail correspondence with Indiana state librarians. Unlike today, no transcriptions of legislative sessions or of individual committee meetings were made.

440 Journal of the House of Representatives, State of Indiana, during the Sixty-Fifth Session General Assembly, Commencing Thursday, January 11, 1907, Regular Session, Volume II (Wm. B. Burford: Contractor for State Printing and Binding, 1907), 302, 367. The Journal digest of the bill on page 302 reads as follows:

Read first time...367, Referred to Committee on Medicine, Health and Vital Statistics...367, Withdrawn...437, Reported back favorably...613, Read second time...718, Engrossed...729, Read third time...1341, Passed the House...1341, Referred to the Senate...1343, Returned from the Senate...2226, Enrolled...2234, Signed by Speaker...2239, Signed by Governor...2415. I have not been able to determine why it was "Withdrawn" and then inexplicably "Reported back favorably." I do know that there was a shouting match one night during a recess of a meeting of the CMHVS.

441 Ibid., 437.

442 Ibid., 612-613. The Indiana State Library, Legislative Section, confirms by personal communication that there are no extant notes from the meeting/s of the Committee.

443 Ibid., 718, 729. 
No. 364 was "enrolled", indicating that the Senate had approved it and sent it back to the House. ${ }^{444}$ Hanley's handpicked Speaker of the House, Rep. Branch, then signed the bill. ${ }^{445}$ On 9 March 1907, Bill 364 was signed by Governor Hanley and was known as Chapter 215, Indiana State Laws. ${ }^{446}$

\subsection{Reactions to the Sterilization Law}

Sharp's friend [Dr. G. Henri] Bogart attributed opposition [to the new law] to the equation of sterilization with castration, and to the lawyer's "worship of precedent."

Angela Gugliotta ${ }^{447}$

The sterilization operation itself was reported as bringing "neither mental nor physical pain." Superintendent Whittaker was of the opinion that men with 10 or 12 years of experience in the "handling of criminals...can see the necessity of something being done along this line.” This article from the Star also gives one of the longer justifications from Dr. Sharp himself.

Heredity is but one of the many causes of degeneracy, and while refined parents may beget degenerate children I make the statement without fear of successful contradiction that no confirmed criminal or other degenerate ever begot a normal child; and for this reason I enter the plea for society in general and for the unborn child in particular that this will be enacted into a law. ${ }^{448}$

Sharp makes an appeal to the duty not to be born, the exact opposite of arguments seen later in Case Two for "protection" for the "unborn child."

Sharp's understanding of genetics was, in hindsight, wrong. In addition, his initial motivation for this policy that was introduced at a Boys' Reformatory and not an adult penal institution was to deal with the "unrefined" habit of masturbation. ${ }^{449}$ We do know that Sharp's very first vasectomy was performed on a 19-year-old man on 11 October 1899. The man was described as being "of criminal heritage", "very dull", "unable to concentrate" and who had "masturbated since age twelve." ${ }^{450}$ The man was said to attribute his mental condition "to excessive masturbation" and vol-

444 Ibid., 2234.

445 Ibid., 2239.

446 Ibid., 85. In the Index of the Journal of the 1906 Legislature the law itself is not indexed with reference to Medicine or Health or Sterilization. Instead, it is indexed under Criminal Institutions. The editor of the Star made no comment on the passage of the bill in his editorial page on the $7^{\text {th }}$ of March. 447 Gugliotta, Sharp with His Little Knife, 389. Note 330.

448 Indianapolis Star, March 7, 1907, 10.

449 Gugliotta, Sharp and His Little Knife, 380. Note 330.

450 Ibid. 
untarily came to Sharp to ask for help with his problem. Sixty days after the vasectomy, the man had gained weight but his erections were as "vigorous" as ever and he claimed that Sharp had "deceived" him. One year later, however, the man's "mental condition had greatly improved" and he had ceased to masturbate through force of will even though the desire was "as great as ever." 451

In January, before the legislature began, the Star had printed a letter-to-the-editor signed by a Mr. Edward Miller of Ft. Wayne, Indiana, which the Editor entitled "Masculine Instinct Outraged." ${ }^{452}$ Here, we have the only mention in a Letter-to-the-Editor format of the sterilization law that would eventually be passed. Horace Read's bill itself had its first reading on 27 January 1907, 18 days after Miller's letter. This would indicate that Miller had been alerted in some fashion to Read's intention to propose the bill and was interested enough to write a letter well in advance of the bill's actual proposal. And in fact, in his letter, Miller tells us how he was informed. He was in attendance "a few weeks ago" at a meeting of township trustees, presumably in Fort Wayne, when Dr. Amos Butler had supported the future legislation. ${ }^{453}$

Miller questioned the entire scheme saying that the "unsexing" of people "because of inability to earn a living, is suggesting something that is barbarous, uncivilized and a violation of the God-given law to 'increase and multiply'." Miller did not spare words in attacking this idea. The idea that because someone is poor, that person should be deprived of the ability to have children was anathema especially "with the rich keeping dogs and fondling them in place of children....." When it came to the idea of prisoners becoming "unsexed", Miller became more analytical and asked:

I would like to know where in the statutes of the [state of] Indiana can be found the authority to do such a thing and even if such a statute was on the law books in Indiana I fail to see where the justice would come in, because the criminal tendency in some form or another runs through every member of the human family, and the fact that men are in the penitentiary does not argue that worse men are not on the outside who are escaping the punishment. ${ }^{454}$

Miller wrote that while eunuchs were "plentiful" in "oriental lands", when "Mr. Butler and his board" turned prisoners into eunuchs and women into "I don't know what to call them", this would not benefit the State in the least. Miller's last impassioned sentence bears repeating:

Lastly, no natural right exists for doing such a thing and if I were convicted of a crime and sent to Michigan City and during my stay there found that on some morning on waking up out of a sleep, my procreative powers were gone by official act of the surgeon, there would be something

451 Ibid.

452 Indianapolis Star, January 9, 1907, 8.

453 Ibid.

454 Ibid. 
doing when I got out and some funerals would take place in advance of the schedule time set by the Creator. ${ }^{455}$

What is interesting is that Miller was the only voice in the pages of the major Indiana newspapers who questioned the impending law. His concerns are based in both legal authority and in a concept of justice, often seen in jurisprudential works under the theme of "practical reason." But practical reason would not be enough to prohibit the law from being passed.

We can conclude that Butler and the IBOSC had actual knowledge of the work of Dr. Harry Sharp in Jeffersonville and that policy entrepreneurs ${ }^{456}$ such as Butler, McCulough, and Hurty plus their institutions endorsed Sharp's work. Indeed, between 1899 and 1907, Harry Sharp had already performed approximately 456 vasectomies at the Indiana Reformatory and information regarding this was freely circulating in both medical and governmental institutions. ${ }^{457}$ Sharp had presented his work at the Mississippi Valley Medical Association already in 1901 and this account had been later published in the New York Medical Journal in 1902. ${ }^{458}$ In 1907, Dr. Sharp also addressed the National Prison Association concerning his work and was elected President of that group on the day after his speech. ${ }^{459}$

Generally the end of a legislative session was unpredictable. It was hectic and dangerous for pending bills and the amount of disorder varied. Sine die in 1907 saw members of the House throwing books and papers in the air. ${ }^{460}$ Both Dr. Hurty and Dr. Butler were pleased with the legislature. Hurty announced that "every important measure" that the State Board of Health had supported had passed into law. ${ }^{461}$ The sterilization law, however, was obviously of small moment to the editor of the Star as he did not include it in a list of Indiana's new laws, although the use of the word "among" in the headline did indicate the list was not exhaustive. He did include information on new laws dealing with such subjects as marriage between first cousins, the prevention of the sale of diseased horses and mules, open season on squirrels, and the wages of Superior and Circuit Court Judges. The Session also passed laws on child abandonment, underage females in wine rooms, police pension funds, brakes on locomotives, increased penalties for banks that accept deposits knowing the bank is insolvent, establishing a Probate Court in Marion County, compelling doctors and

455 Ibid.

456 Please see, Nancy C. Roberts and Paula J.King, "Policy Entrepreneurs: Their Activity Structure and Function in the Policy Process" in Journal of Public Administration Research and Theory, 1 (1991), 147-57.

457 Gugliotta, Sharp and his Little Knife, 380. Note 330.

458 Ibid.

459 Ibid.

460 Indianapolis Morning Star, March 12, 1907, 4.

461 Indianapolis News, March 12, 1907, 2. 
health officers to make reports to the State Board of Health, and the "blind tiger" law. ${ }^{462}$ Amos Butler also noted that a full 36 bills that were related to charities passed both houses and he expected the Governor to sign at least "most" of them. ${ }^{463}$

In March 1907, two days after the legislative session ended, the Star's Editor found time to address the sterilization law. His arguments in favor of the bill were structured around two ideas. The first was that some people are so "abnormally constituted" that they take to crime like "the duckling takes to water or the skylark cleaves the blue vault of heaven." ${ }^{464}$ There was something so "radically wrong" with them that it would have been better if they "had...never been born." The second idea, which can be called the "farmer's practical knowledge" is that, in the animal world, "we know how to deal with this problem." 465 By not paying careful attention to breeding in humans, the editor said:

we have shirked a duty to the unborn degenerate who is called into the world only to be destroyed, soul and body, by the inherited forces of evil that push him on to crime and ruin. ${ }^{466}$

Criminals were not the only focus of the legislation, however. The law applied to "confirmed criminals, idiots, imbeciles and rape fiends." The Editor wrote that the surgeons who would do the operations at the Indiana Reformatory were said to be "of the highest standing." Granted, it was an "experiment" that the "scientific men and criminologists" around the world would watch with interest, but the effort had to be made. And, if the work were "approved by experience" then it would solve the problem of the "multitudes of men and women, foreordained to almost certain physical, social and moral ruin.” This type of reductionist thinking predominated the analyses we find at this specific time.

It is also interesting to read the notion that there is a duty to the "unborn degenerate." This can be contrasted with the "fetus as a person" ideograph one reads in today's press. In 1907 this Editor could write of a right not to be born if the birth was of a "degenerate" person, whereas a century later, one could read of a duty to give birth no matter what the condition of the fetus is, because it was a "person." Human rights that accrue to the "personhood" of the fetus, based on the likely future that child might have, have, within a one hundred year period, been successfully exchanged from the duty not to have a particular type of child ${ }^{467}$, to the right of the fetus to be

462 “Among Indiana’s New Laws.” Indianapolis Morning Star, March 12, 1907, 8. The “blind tiger” bill is a reference to the regulation of alcohol.

463 Indianapolis News, March 12, 1907, 4.

464 “Crime at its Source.”Indianapolis Morning Star, 1March 13, 1907, 8.

465 As we shall see in the second half of this Case, this same approach was used in the Norwegian debates.

466 Gugliotta, Sharp and his Little Knife, 380. Note 330.

467 This is as defined by the culture and society of the time. 
born, no matter what its likely circumstances. In other words, within a 100-year span, considerations of what type of future the child might have been semiotic ally subtracted from the "personhood" of the fetus.

Passage of Chapter 215 into law was met over the ensuing years with several challenges from several quarters. Indeed, questions as to the constitutionality of the measure appeared immediately after Sharp had given his talk supporting the measure at the National Prison Association in early 1907. A panel assembled after his talk to discuss Indiana's sterilization law. The panel was composed of Dr. Sharp, Superintendent Whittaker, Cuban military officer and leper colony superintendent General Garcia, Indiana Attorney General James Bingham, Ohio State Reformatory Manager H.F. Coates, Representative Dr. Read and Chicago Judge Henry V. Freeman. ${ }^{468}$ Of this group, comments by Bingham and Freeman are the most interesting. Freeman was a justice of the Branch Appellate Court for the first district of Illinois in Chicago and also a lecturer on "legal ethics and medical jurisprudence" at the University of Chicago. ${ }^{469}$ Bingham "worried about "the unsoundness of the principle of emasculating a perfectly sane person unless it is imposed as part of the penalty." "470 However, he did not have a problem with the right to do the operation as a measure to "relieve disease." 471

As Gugliotta notes, the panel itself reflected a rivalry between the medical and legal profession over the issue of sterilization. It also reflected the "broader Progressive Era conflict between the courts and elected officials on the one hand and legislatively established panels of experts on the other." 472 Whittaker weighed in on the debate with the opinion that it was the perspective of the medical doctor and not the government or courts or citizenry which should prevail. Garcia worried that sexual unions of the defective only created more defective children who would then become dependent on the state. Coates related his experience with a potential parolee who could not help himself from committing sodomy. The assembled men were concerned about various aspects of crime control, more effective institutionalization and disease control as well as normative morality. None, even the attorneys, voiced the idea of a basic human right to procreate or to have a sexual preference.

After the Hanley term of office, "strong” opposition developed against the law, primarily because of its lack of due process safeguards. Hanley's successors, Governors Thomas Riley Marshall (Democrat) (1854 -1925) and Samuel Moffett Ralston (Democrat) (1857-1925) stopped enforcement of the law during their terms of office, from 1909 to 1917. Finally, in 1921, fourteen years after the passage of the sterilization

468 Gugliotta, Sharp and his Little Knife, 390. Note 330.

469 Ibid., Footnote 86.

470 Ibid., 390.

471 Ibid.

472 Ibid., 391-392. 
law, Chapter 215 was challenged in the Indiana Supreme Court ${ }^{473}$ and was found to be invalid as it violated the procedural due process clause under the Fourteenth Amendment of the federal Constitution. This finding is reported at Williams v. Smith, 190 Ind. 526, 131 N.E. 2(1921).

The Williams challenge had originated from the Clark Circuit County and Judge James W. Fortune, although Gugliotta writes that the successor to Governor Ralston (1913-1917), James P. Goodrich, had "arranged" the constitutional test case, through use of an injunction. ${ }^{474}$ It was an action "by Warren Wallace Smith, [and] by Lincoln E. Lankford, his friend, against Charles F. Williams and others." 475 Smith had won at the local level and the defendants had appealed. Ele Stansbury and Edward M. White argued in the highest court for the institutional appellants Williams, while Wilmer T. Fox had represented the prisoner appellee, Smith.

In the end, Judge J. Townsend of the Supreme Court affirmed the ruling by Circuit Court Judge, James Fortune. Townsend's decision is short, consisting of three basic paragraphs and is a classically written decision, based on precedent. The first paragraph merely outlines the statute itself. The second cites to a District Court case from South Dakota, Davis v. Berry, 216 F. 413 (1914) which itself refers to a similar statute from Iowa. Davis had said that:

The hearing is by an administrative board or officer. There is no actual hearing. There is no evidence. The proceedings are private. The public does not know what is being done until it is done. Witnesses are not produced, or if produced, they are not cross-examined....The prisoner is not advised of the proceedings until ordered to submit to the operation....Due process of...law means that every person must have his day in court, and this is as old as Magna Charta; that sometime in the proceedings he must be confronted by his accuser and given a public hearing. ${ }^{476}$

The third paragraph merely notes that the prisoner and appellant Smith had not had the opportunity to confront his accusers. He had no chance to have experts of his own choosing to present contrary evidence. Smith had no chance "to controvert the scientific question that he is of a class designated in the statute." 477 The statute violated the $14^{\text {th }}$ Amendment of the federal Constitution since Smith's due process rights had been violated. Although Townsend's short opinion meets every requirement of judicial decisional drafting, his reference to the summary taking of the prisoner to the operation is as chilling as any one could ever read. And, his observation of exactly how the class of "confirmed criminal" could be proven and by what scientific evidence

473 In 1900, the Supreme Court of Indiana consisted of 5 members who were elected from districts by the state at large. Their term was 6 years in length. An appellate court had been established in 1891 in addition to the circuit and county court system already in place.

474 Gugliotta, Sharp and his Little Knife, 403. Note 330.

475 Williams, et. al. v. Smith, 190 Ind. 526 at 526, 131 N.E. 2 (1921).

476 Williams v. Smith, 190 Ind. 526 at 527, 131 N.E. 2 (1921).

477 Williams v. Smith, 190 Ind. 526 at 528, 131 N.E. 2 (1921). 
hints at more problems with the statute. Even if the statute had provided for a type of due process, would the legislature have included the "standard of proof" needed for this proof? That the statute should have been successfully challenged speaks to the standards of a small minority of the legal profession in Indiana, especially since the social climate in the state and in the country had produced decidedly different goals than one reads embodied in the statute. It also substantiates Gugliotti's assertion that there was indeed a "rivalry" between the medical and legal professions for control of this epistemic imbroglio.

But this was not the end of the law in Indiana and it was resurrected in 1927 and amended numerous times between 1931 and the 1950s. ${ }^{478}$ Defects in the statute were remedied in 1927 in Indiana Acts, Chapter 241. This law provided for a thirty-day notice to the inmate and/or prisoner or their guardians in which to prepare a defense, appeasing those with a due process concern. The Act was further amended in 1931 in Indiana Acts 1931, Chapter 50. This amendment mandated that the physician who applied for sterilization of an idiot, imbecile or feeble-minded person had to certify whether this condition was due to bad genes or if the person was "cacogenic." 479 In 1935, in Indiana Acts, Chapter 12, the bill was again amended to include insane persons as within the jurisdiction of the law. ${ }^{480}$ A check of Westlaw Shepard's indicates that the law is still in force and effect, not having been repealed or overturned; it is similar to many laws that are "on the books" but no longer utilized. ${ }^{481}$

Criminals may have been protected - to an extent - from sterilization after the Williams decision in 1921 and the 1927 and 1931 amendments to Chapter 215. Nonetheless, nativism surged in Indiana after World War I. For example, the United States Army had collected data from soldiers entering its ranks during that war and found that while northern Europeans scored "almost as well as native whites...[soldiers who were] black, ... and soldiers born in Latin and Slavic countries averaged significantly lower." ${ }^{482}$ This type of information only served to fuel the energies of eugenicists such as Senator Carl E.O. Holmes from Gary, Indiana. Before running for the legislature,

\section{Ibid.}

479 "Cacogenics" is defined as "The study of racial degeneration.” in William Morris (ed.), The American Heritage Dictionary of the English Language (Boston: Houghton Mifflin Company, 1970), p. 185.

480 Please see source http://www.statelib.lib.in.us/www/isl/indiana/eugenics.html, accessed 12 December 12, 2007.

481 Westlaw Shepard's is a method for determining if a case is still "good law" in the United States. In addition to noting if the law has been "overruled", it also notes if various portions of the law have been "questioned", etc. This is not the first time this type of anomaly has occurred, i.e. where older laws remain "on the books", despite presumptive invalidity. See Indiana Law Journal, Notes, Volume 38, 1962-1963, p. 276. "Subsequent to the Williams decision, however, procedurally refined statutes providing for the sterilization of the mentally ill and mentally defective were enacted and remain a part of the present law in Indiana [as of 1962-1963].”

482 Walsh, Centennial History, 308. 
Holmes, a banker and realtor of Swedish ancestry, had been a member of the state Committee on Mental Defectives. After election, he proposed the 1925 amendment to Chapter 215 that would have required the appointment of a state eugenicist who, after studying the wards of the state, could have recommended sterilization for some if they "might reproduce their kin, i.e. more inmates for the states institutions." 483 The act itself was entitled "an act to prevent the procreation of persons socially inadequate from defective inheritance..." ${ }^{484}$

Rep. William Brown of Porter County tried to add an amendment to Holmes' bill to the effect that no one who became a subject of the law could be used for experimentation, but this measure failed. ${ }^{485}$ The Indianapolis News was an enthusiastic sup-

\section{Ibid.}

484 Ibid.

485 Prisoners at Jeffersonville were not the only human subjects used in the pursuit of scientific progress. Since the work at Tuskagee is so well known, we often overlook experimentation done before that time. In 1906, the News included a story of national importance with the headline "Plague Germs in Prisoners' Bodies. Mistake at Bilibad Likely to Result in Resignation of Dr. R.P. Strong. Wrong Tubes Were Used. Attendents Thought They Were Inoculating Victims with Cholera Serum - Natives Indignant.” (Indianapolis News, 3 December 1906, p. 1. The News misspells the word Bilibid.) Bilibid Prison was the main prison for the Philippines, located in the capitol, Manila. In 1899 Lt. Richard P. Strong along with contract surgeon Joseph J. Curry, as members of the U.S. Army, began to investigate tropical diseases; later, Strong would become the head of the Philippine Biological Laboratory a division of the Philippine Bureau of Science, a civilian laboratory in Manila whose work was to vaccinate against cholera and the plague. On the $16^{\text {th }}$ of November 1906, Strong inoculated 24 prisoners who were inmates at the Bilibid Prison with a cholera vaccine that happened to be either contaminated with bubonic plague microorganisms or with only the plague organism present. Various explanations for this ensued. One such explanation was that a visiting doctor from Chicago had mixed up the test tubes and Strong had not have locks on test tube racks. After being inoculated, thirteen of the twentyfour prisoners died. Another explanation exists which is not so benign and implies intent beyond simple negligence. This explanation posits that the governor-general granted permission for "investigation among inmates of Bilibid Prisons with reference to diseases which prevail among them." Iatrogenic Plague Disaster (1906), www.brown.edu/Courses/Bio_160/Projects2000/Ethics/IATROGENICPLAGUEDISASTER.html, accessed on March 8, 2006.

To be fair, Strong did use vaccines on himself as well as the prisoners. But on 16 November he simply asked the prisoners to stand in a line and inoculated them without their permission and without telling them what he was doing. The governor general had used the word "prevalent" in his permission but neither the plague nor cholera was prevalent in 1906 and this permission "did not imply or extend to the trial of prophylactic experiments." (Ibid.) A general committee was appointed by the Governor General to investigate the incident and Strong was eventually not found guilty of negligence. No mainland investigation was undertaken either and six years later, Strong was given access to the prisoners to conduct experiments on beriberi, also with fatalities; survivors were compensated with cigars and cigarettes. (Allen M. Hornblum, "They were cheap and available: prisoners as research subjects in twentieth century America”, in BMJ, 315 (1997), at http://bmj.bmjjournals. com/archive/7120/7120ed1.htm. Please see, Eli Cherin, "Richard Pearson Strong and the Iatrogenic Plague Disaster in Bilibid Prison, Manila, 1906” in Review of Infectious Diseases, 11 (1989), 9961004 and Campbell, K. A., "Knots in the fabric: Richard Pearson Strong and the Bilibid Prison vaccine 
porter of the Holmes measure as were Senators Robert L. Moorhead and Thomas A. Daily who, just before the bill passed the Senate by a vote of 31 to 12, stated that every man should set out his pedigree "just as we do for our pedigreed hogs and cattle."486 The bill went to the House where it was assigned to the Committee on Agriculture not the CMHVS as before - and where it was reported out without any recommendations. Charles Mendenhall of Marion County then successfully made a motion and it was "indefinitely postponed", essentially a death decree. ${ }^{487}$

Estimates of the total number of persons sterilized before officials either refused to utilize the law or it was ruled invalid, range from 2,000 to 2,500.488 Alexandra Minna Stern writes that about 2,000 inmates at various state institutions were sterilized between 1927 and 1974; the "the statutory basis for these operations was the 1927 sterilization act and several subsequent amendments that Indiana legislators carefully crafted to preclude problems that doomed the 1907 law." ${ }^{489}$

\subsection{Jasanoff Fields Reflected in the Indiana Media}

I begin this section with two examples of the shifting articulations among and between the Jasanoff fields of knowledge co-production. They demonstrate the microlevel discursive work that was done by religion and the law to support the pseudo science of Eugenics.

The first example is one where representations of science and progress were fused with the institution of religion. The Indiana sterilization law was the subject of comment on 18 March 1907 at the Roberts Park M.E. (Methodist Episcopal) Church in Indianapolis where Dr. Albert Huristone took as his text Romans xiv, 12 in his sermon "Heredity and Responsibility." That religious groups should comment on this new law is not surprising. The divisions between Christian sects in their support and nonsupport for sterilization are of interest, however. Using the same "animal improve-

trails, 1905-1906” in Bulletin of Historical Medicine, 68 (1994), 600 -38.) Strong was later made a Professor of Tropical Medicine at Harvard University.

486 Walsh, Centenial History, 308.

487 Ibid.

488 Please see, http://www.hmdb.org/marker.asp?marker=1829, accessed May 15, 2009. See footnote number 7 .

489 Stern, Sow's Ear, p. 20. Note 347. While it would be soothing to believe that legally and ethically problematic bills such as the sterilization bill of 1907 were a thing of the past, we would do well to note a bill submitted in 98 years later. In 2005, General Assembly of the state of Indiana entertained a proposed bill by Republican Senator Patricia Miller to ban unmarried women, gay men and lesbian women from using assisted reproductive techniques in order to have children. (Ruth Clifford Engs, “Relieved That Indiana Won't Embarrass Itself Again” (Op-Ed), Indianapolis Star (Gannett), 9 October 2005.) 
ment" argument, Huristone applauded the Legislature asking if "the same common sense "which is manifested in the improvement of the stock on the farm"' wasn't being used in the Legislature ${ }^{490}$ Echoing the remarks made by the Editor of the Star and Dr. Sharp, above, Huristone said society is responsible "not only to the living but to the unborn." When compared with the $21^{\text {st }}$ century religious political rhetoric of life beginning at the moment of conception, Huristone's statement can be seen in at least two ways: either he did not believe - as a minister - that life began at birth or, if he did, he apparently supposed that the greater responsibility was owed to the living and/or future generations.

For Dr. Huristone, science simply "reinforced the doctrines of the Bible."

According to the accounts reported of his sermon, Huristone then wove this idea, that modern concepts of heredity did not abrogate responsibility, into reflections on the political topics of the day. He addressed the legal issue of insanity, which is the subject of my second example, below. Huristone said that " "fits of temporary insanity"” which he called "brain storms" did not absolve one from responsibility. Heredity "did not destroy personality" and thus, even if we inherited certain tendencies, they were only influences and do not destroy "moral responsibility." Huristone also commented on the new Juvenile Court system saying that if the weaker were lead by "some strong probation officer, some worthy citizen", that they could outrun these tendencies.

In the end, Huristone's strategy was to leave no rhetorical space whatsoever between his concepts of religion and "heredity."

The Christian church has taught the doctrine of heredity for two thousand years, only people did not like the term original sin. But Mr. Darwin has made us all orthodox and now everybody believes in inheritance! The Jewish church long ago taught that the 'iniquity of the father is visited upon the children to the third and fourth generation.' [A]nd in modern times science comes to the side of the moralist teaching that there is as much heredity in crime as in consumption, cancer or insanity; what the pulpit has called 'parental influences' or 'the iniquity of the father,' biology would call heredity. ${ }^{491}$

This is an interesting rhetorical slight of hand, a prescient attempt to reconcile the seemingly insurmountable, inherent problems between religion and science that would soon become apparent.

But the institution of religion was malleable. Huristone could not only use it preemptively as not being antithetical to science but it could also be used in a prospective manner to support nationalism. We find that the very next day in the Star, in a letter

490 Indianapolis Star, March 18, 1907, 14.

491 Ibid. 
to the Editor, a Mr. S.O. M'Clung from Williams, Indiana, used the Christian Bible to underpin the idea of "American exceptionalism" or America as the "new Eden." ${ }^{992}$

My second example of how co-productionist fields intersected is that of representations made by Psychology and the institution of the Law. Scientific "experts" were a regular feature in Hoosier newspapers, and especially in connection with the famous Harry Thaw trial. Thaw had allegedly murdered architect Stanford White who was the cosmopolitan descendant of two American presidents. Henry Adams had dubbed White the "Moses of Manhattan's niveau riche." 493 Jealousy of actress Evelyn Nesbitt's previous involvement with White before her marriage to Thaw had lead Thaw the "eccentric millionaire playboy" - to shoot White on the roof of the old Madison Square Garden.

In January, 1907 opinions about the defendant, Henry Kendall Thaw, by the "famous criminologist" Cesare Lombroso (1836-1909) were printed on page one of the News. ${ }^{494}$ In the classic rhetoric of eugenics, Lombroso noted that Thaw was a "hereditary degenerate." Lombroso, who worked vigorously to spread eugenic thought in Italy during the early part of the century, concluded that Thaw was "born a degenerate” and that Thaw's "epileptiform madness" was traceable to Thaw's mad aunt and the exhaustion of Thaw's father by the work that made him a millionaire. ${ }^{495}$

For weeks, the trial of Harry Kendall Thaw, held in New York City, had captured the imagination of Indianapolis readers. It was called "copy catnip" and would be, from 1906-1908, the "trial of the century" taking a place alongside other great and better-known American trials such as the Scopes, Lindbergh/Hauptmann, Sheppard and Simpson trials. ${ }^{496}$ The Star reported on 11 April that the first Thaw trial, begun on 23 January 1907 and ended that day, was on the brink of being called a mistrial, since, after only 6 hours of deliberation, jurors were unable to reach a unanimous decision. ${ }^{497}$

Later, after debating for 47 hours, the jury deadlocked - seven in favor of conviction on the charge of Murder in the First Degree and five for acquittal. ${ }^{498}$ Thaw's wife Evelyn had emerged from this trial as "the chief figure around which the drama revolved." The Editor of the Star could not help but comment on the mistrial as a "miscarriage of justice" calling Thaw a "conscious murderer if ever there was one." More important for my purposes here, he also commented on the defense that Thaw's attor-

492 “Views of the People.”Indianapolis Star, March 20, 1907, 8.

493 Ronald Goldfarb, “The 'Trial of the Century”” in Cosmos Journal, Walter G. Berl, Editor, 1998. This can be viewed at http://www.cosmos-club.org/web/journals/1998/goldfarb.html, accessed December 6, 2007.

494 Indianapolis News, January 21, 1907, 1.

495 Ibid.

496 Goldfarb, “The 'Trial of the Century'.” Note 678.

497 Indianapolis Star, April 11, 1907, 1. Upper Left.

498 Indianapolis Star, April 13, 1907, 1. Upper Left. 
ney, Mr. Delmas, had used - the so-called "dementia Americana” defense, denouncing it as "against public policy" and an "anarchistic doctrine of the unwritten law."499 In a second trial a year later, Thaw was acquitted by reason of insanity, and Thaw was "hailed by the public as a hero in an American morality play." 500

What this trial did do was to highlight the ever-increasing intersections between the relatively new sciences of Psychology with the Law, just as the Scopes trial would spotlight the science-versus-religion debate in American culture a few years later. Here, a heightened sense of moral panic is alluded to as "dementia Americana" and is malleable enough to be used as a positive notion by a good criminal defense attorney. In his closing statement to the jury, defense attorney Delmas said:

\footnotetext{
...if you desire a name for this species of insanity let me suggest it - call it dementia Americana. That is the species of insanity which makes every American man believe his home to be sacred; that is the species of insanity which makes him believe the honor of his daughter is sacred; that is the species of insanity which makes him believe that whosoever invades his home, that whosoever stains the virtue of this threshold, has violated the highest of human laws and must appeal to the mercy of God, if mercy there be for him anywhere in the universe. ${ }^{501}$
}

But this is also an example of epistemic networks that transgress disciplinary boundaries. And, it is also this very same juridical issue that I will describe in the second half of this Case.

In Norway in 1934, a court addressed the case of a Norwegian woman, Aagot Hansen, who was sent to an insane asylum for years although she was not clinically insane. This is the antithesis of the Thaw case and will be discussed below. These two cases were not simply a "powerful nexus of concerns with national identity, patriarchy, class and the public sphere..." 502 but also were an account of the embryogenesis of new legal epistemology through the use of a dialogic narrative. ${ }^{503}$ The two examples also demonstrate which intersubjective group was in power and which was not.

In the United States, changes in the law of insanity were a major phenomenon within the legal community but were also no small matter in society at large. On 16 April, a mirror-image case of Harry Kendall Thaw opened in Lafayette, Indiana, except

\footnotetext{
499 Ibid., 8.
}

500 Goldfarb, Trial of the Century. Note 678. The fictionalized account of the trial can be had in E.L. Doctorow's novel Ragtime.

501 Chicago Daily Tribune, April 10, 1907, 1. (Emphasis mine.)

502 Adrienne L. McLean and David A. Cook, "Headline Hollywood: A Century of Film Scandal" in Film Quarterly, 55 (2002), 54.

503 Martha Merril Umphrey, "Dialogics of Legal Meaning: Spectacular Trials, the Unwritten Law, and Narratives of Criminal Responsibility" in Law and Society Review, (BNET Research Center, 1992) at http://findarticles.com/p/articles/mi_qa3757/is_199901/ai_n8843631/print, accessed December 12, 2007. 
that the defendant was a woman, Alice Cooper Lawsen. ${ }^{504}$ Lawsen had killed her husband, Charles A. Lawsen, a saloon-owner, and the issue as reported was whether she had done so "deliberately and with premeditation." ${ }^{505}$ The reporter speculated that Lawsen would use the new insanity defense.

One final phenomenon must be mentioned in relation to the state of Indiana the United States - being the state in the first country in the world to successfully legislate a forcible sterilization law. Of the intersubjective categories that I have discussed in Chapter 2, I have chosen - in the main - to write about women as a category, although race/ethnicity is also often mentioned. The Indiana law began with its object as the male body, the bodies of young male prisoners in a juvenile institution. But the law did not confine itself to this category and it soon expanded to the body of an adult male chicken thief before the law was overturned. Meanwhile, the bodies of women were affected and continued to be affected well after the eugenics movement retreated from discourse. ${ }^{506}$

\subsection{Eugenic Discourses in the Norwegian Parliament, 1934-1936}

Here we have 100 idiots which cost society so much money. For the same amount of money we can support 200 healthy children. Of these two groups, a significant number will die of inadequate nourishment etc., if we have nothing to support them because we have to use the money for the maintenance of the idiots. What should we do?

Dr. Jørgen H. Berner ${ }^{507}$

I fear...the so-called 'objective’ scientist when they are dealing with problems that are not strictly scientific.

Dr. Otto L. Mohr ${ }^{508}$

The composition of the 150-member Norwegian Storting from 1934-1936 by political party shows a robust plurality identified as Labour Party (Ap) members (68 members of the 150-member Storting, or 45.3\%). ${ }^{509}$ Conservative (H) members numbered 30

504 Indianapolis Star, April 16, 1907, 5.

505 Ibid.

506 Please see Allison Carey, “Gender and Compulsory Sterilization Programs in America”, 74-105. Note 208. I will analyze her research below.

507 Aftenposten (a.m. Edition), August 29, 1934, 2.

508 Library of Congress (Washington, D.C., U.S.A.), Papers of Margaret Sanger, Accession Number 16,700, Vol. 29 Reel 19. Letter dated May 11, 1926. Letter dated Oslo, 8/11, 1927 by Otto Mohr, end page two and begin page three.

509 Please see source http://www.norgeslexi.com/politikk/storting/representatnt/34-36.html, accessed December 9, 2007. 
(20\%), the Liberal Party (V) had 25 members (16.6\%) and the Farmers Party (B) had 23 members (15.3\%). Other parties had which had only one member were the Society Party (Samfundsparti), the Kr-R Party, the R-F Party and the F-F Party. ${ }^{510}$ Together, the latter 4 parties with one member each composed $2.4 \%$ of the Storting.

Born in 1859, the oldest member of the Storting was 75-year old C. Hornsrud; he was a Labour Party member and farmer ${ }^{511}$ from Buskerud. The youngest Storting member was also a Labour Party member; this was K. Fonstad, a telegraph operator from Hedmark. In addition, the Storting, unlike the Indianan legislature, had three women members; 59 year old Helga A.A. Ramstad, a Labour Party member and caretaker $^{512}$ from Akershus, 52 year old Helga A. Karlsen, a Labour Party member and housewife from Oslo, and finally, 46 year old Signe Swensson, a Conservative Party doctor from the Trøndelag area of Norway. ${ }^{513}$

The occupations of the members can be generalized in that, from the professional class of workers, i.e. attorney, doctor, lector and rector, only $6(4 \%)$ were elected to the Storting - a meager number when compared with the Indiana legislature. Of the class of workers that we now term "white collar" workers, i.e. state administrative workers and other professionals, 20 (13.3\%) were elected. Those who were identified as employed in a Bank, or identified as a Merchant or Manager numbered $16(10.6 \%)$. These three groups, when combined with the 20 (20\%) other "white collar" workers, gave the largest voting bloc - by class - of 62 members (47.9\%). The second largest group - by occupation - was composed of farmers, fishermen and other "blue collar" workers. The farming group was comprised of 46 (30.6\%) members, fishermen totaled 4 members $(2.5 \%)$, and $18(12 \%)$ can be identified as "blue collar"; together these three groups had 68 (44.5\%) members. Finally, 10 (6.6\%) teachers had been elected to this Storting.

In 1934, a majority of the general population of Norway were members of Den Norske Kirke (DNK) and nothing that I have found indicates that any of the members of the 1934-1936 Storting were non-members of the national church of Norway, DNK.

As part of their ordering function, institutions are "stable repositories of knowledge and power" and are also "inscription devices" for society. ${ }^{514}$ Institutions can extend across political and geographical boundaries and in this sense, have been especially since the formation of academic journals - no stranger to the concept of globalization. The globalization effect, in 1934 essentially meant that, although journals flowed freely across the globe, Norway looked to how other Nordic countries

510 I have been unable to find the full names of the last three parties, mentioned only by their acronyms.

511 "Gårdsbruker."

512 "Vaktmester."

513 Appendix D lists the compositioin of the Storting by part affiliation and occupation.

514 Jasanoff (ed.), States of Knowledge: the co-production of science and social order (London, Routledge, 2004) 39-40. 
were using scientific principles, including eugenics. As we can read in various pre1934 Justice Committee minutes where the Norwegian sterilization law was discussed, it was Nordic countries that were mentioned with approval as having taken similar steps. This was in addition to the United States, Germany and Great Britain.

As institutions - or institutional structures - both medicine and law in Norway were well established in 1934. In fact, the institution of law was powerful enough for a Norwegian to lead the Congress of Ministers of Justice on 29 November in Stockholm. Attending the Congress, at the instigation of Justice Minister Schyter of Sweden, were Justice Sunde of Norway ${ }^{515}$, Zahle of Denmark and Zeriachius of Finland who joined the other 400 participants in Stockholm. ${ }^{516}$

The medical profession was also a powerful institution in Norway, as in Indiana. One of the indications of this is how the subject of euthanasia was addressed as part of the “zeitgeist” of 1934. In Aftenposten's kronikk of 29 August 1934, we read the headline "Should Doctors Have the Right to Take the Life of Patients?"517 Dr. Jørgen H. Berner, who was the General Secretary of the Norwegian Doctor's Association and Editor of its Journal from 1925 to 1949 , wrote the editorial. ${ }^{518}$ Berner began his editorial by citing to the English Parliament which that fall was set to consider the suggestion in its session. Berner also cited to German criminal law, which, it was rumored, would allow such action under certain conditions. ${ }^{519}$

Berner grabbed the reader's attention by mentioning unfortunate - and emotionally charged - accidents; these included a child who had swallowed lye in Sweden and the case of a child born with central nervous system problems. He then cited newspaper articles by Dr. A. Brinchmann in the 16 November 1933 edition of Aftenposten and Dr. Johann Scharffenberg in the 17 October 1933 edition of Arbeiderbladet that had both dealt with the question of developmentally delayed children and their right to live. ${ }^{520}$ But Berner was more eager to address those who were chronically unhealthy and sick, "in the first place those children with essentially mental or bodily defects which make them a burden for their caretakers and society." ${ }^{21}$ Acknowledg-

515 Sunde was also a member of the Storting's Justice Committee that approved the 1934 law; his comments can be reviewed in Appendix E.

516 Aftenposten (a.m. Edition), November 29, 1934, 3. Halvard Olsen opened the Congress but four Directors were then chosen to lead the meeting including Oscar Torp, who later became Labor Prime Minister from 1951-1955.

517 Aftenposten (a.m. Edition), August 29, 1934, 2. Aftenpostens kronikk, "Bør lægene ha rett til å avlive patienter?" Please see fn. 495 for definition of "kronikk."

518 Tidskr. Nor Lægeforen 2002, 122, 121.

519 Aftenposten (a.m. Edition), August 29, 1934, 2. “og for ett år siden forlød det at i Tyskland var fremsatt et forslag til ny straffelov, som bestemte at under visse omstendigheter skulde det være tillatt å ta livet av en patient..” The entire question - of euthanasia - had also taken up in a book entitled “And So Life Continues” by Lalli Løvland.

520 Ibid.

521 Ibid. 
ing that the issue of "social" and "humanitarian" indications for the termination of a pregnancy was a matter of debate, Berner noted that a number of "ethical, esteemed people have suggested reforms along this line”, allowing abortion, and agreed with Scharffenberg, who would allow abortion. ${ }^{522}$ But Berner thought that Schaffenberg and others were inconsistent in that they opposed taking the life of the developmentally delayed but would agree to permit abortion for social and/or humanitarian reasons.

Berner argued that society allowed the "disposal" of fetuses, which for social or economic reasons were not wanted and the killing of a fetus was allowed if it threatened the life of the mother. But with those children who were "deformed", he was of the opinion that it would be better if they had not been born. His opinion was that not to allow for this was a matter of inconsistent thinking, i.e. to assign a newborn rights while not assigning the unborn any similar rights. ${ }^{523} \mathrm{He}$ argued that a society is judged by how it cares for the "defective" person who cannot care for him or herself. ${ }^{524}$ For Berner, it was a slippery slope that society faced when it allowed abortion based on "social" or "humanitarian" indications. "The veneration of life" was an absolute for Berner and the "humanitarian" indication merely a path to ethical slippery slopes. While Berner seemed to be trying to address inconsistencies in the abortion reform movement, he might have done his argument no obvious good by advocating for euthanasia for those who were chronically sick or unhealthy and by proposing that a medical doctor make that decision.

Aftenposten was sometimes used as if it were an academic journal and included many more scientific discussions than did any newspaper in Indiana in 1907. The Kronikk in the Aftenposten was also basically used as an editorial forum that frequently allowed one or another scientific professional - usually either scientists or doctors - to promote a "scientific" opinion. And the one issue that involved both of these institutions was the issue of whether or not to reform the then-existing abortion law in Norway, the Criminal Law of 22 May 1902, §245 to allow for women to have abortions within three months of conception.

On 3 January 1934, Professor, Dr. R. Ingebrigtsen (b. 1880) wrote an article that was placed on page one of Aftenposten, at the upper left had side of the front page, a place routinely used for the most important news of the day. ${ }^{525}$ This lengthy article delved into the relative success of the Danish sterilization law, which by 1934, had already been in effect for four years. Danish state's attorney Goll had given results

522 Ibid. “...Scharffenberg som dog fordømmer såvel abortus provacatus og avlivning av idioter, etc.” 523 Ibid. “... så synes det dog å være ganskje inkonsekvent å tildele det fødte barn alle rettigheter ...det ufødte barn dem.”

524 Ibid.

525 Aftenposten (p.m. Edition), January 3, 1934, 1. 
from those four years to a meeting of the Criminal Biology Association that had been held in Hamburg, Germany in June of the previous year. ${ }^{526}$

Ingebrigtsen was a medical doctor and he was a crucial part of the articulations between law and medicine at this time, helping to impact the impending sterilization law though feature articles such as this. ${ }^{527}$ In his article, after giving a technical explanation of sterilization in men and women, Ingebrigtsen explained under what conditions or "indications" the operation should proceed. The first was as "medically indicated" where the health or life of the patient was in question. As an aside, he noted that one could not consider it a "medical indication" if the patient were castrated because he masturbated excessively or was an exhibitionist. This was a somewhat more liberal position than in the Indiana law because, as he noted, although these conditions were troublesome, and if inherited could lead to imprisonment or punishment, they did not affect the (medical) health of the patient. ${ }^{528}$ But Dr. Ingebrigtsen's opinion was that, as the law was written in 1934, castration for "medically" indicated conditions would be allowed. The new draft law, however, would add other categories; these were 1. humanitarian, 2. social, 3. criminal management, and 4. eugenic or any combination of these such as social-eugenic. ${ }^{529}$

Ingebrigtsen went on to give an example of each of the four categories. The example he gave for the first category, "humanitarian" was if a patient were a homosexual or an exhibitionist. After having been dealt with by the criminal system, the offender could be castrated if there were a chance of recidivism or new violations. Ingebrigtsen thought the life of the offender in that situation would become easier with the possibility of uninterrupted freedom. ${ }^{530}$ As to the second category "social",

526 Ibid., 6.

527 Ingebrigtsen was a Professor of Surgery at the University of Oslo in 1934. Interestingly, he had also been a Fellow at the Rockefeller Institute for Medical Research in New York with Dr. Alexis Carrel (1873-1944) from 1911 to 1913. (Gram, Harald and Steenstrup, Bjørn (Publishers), Hvem er Hvem? (Oslo: H. Aschehoug \& Co. (W. Nygaard), 1939). p. 319.) In 1912, Carrel won the Nobel Prize for his work in physiology, and along with Charles Claude Guthrie laid the groundwork for the artifical heart. Carrel was recruited to the Rockefeller Institute for Medical Research in 1906 but was later forced to resign. In 1935, he published a book entitled Man, The Unknown where his eugenic ideas were included and, in the 1936 Introduction to the German edition alone, praise for the Nazi Regime. In 1941 he became Regent of the Fondation Française pour l'Etude des Problemes Humans from which the Minister of Health suspended him after the liberation of Paris. In the 1990s, historian Arthur Schlesinger, Jr. implicated Carrel in the racism of Charles Lindbergh saying "I suppose he got it a lot of it from Alexis Carrel, the French Biologist who had a kind of racial mysticism of a sort.” See PBS interview at http:// www.pbs.org/wgbh/amex/lingbergh/filmmore/reference/interview/schlesinger03.html, accessed July 5, 2009. Also see Gugliotta on Carrel.

528 Aftenposten (p.m. Edition), January 3, 1934, 1, continued to 6. An example of possible criminal prosecution would be for exhibitionism.

529 Ibid.

530 Ibid. 
Ingebrigtsen mentioned people who are of "inferior value" such as the developmentally disabled and mentally ill, all of whom could be presumed to be unable to care for his or her progeny. ${ }^{531}$ The reasoning behind this social category was, for Ingebrigtsen, purely economic. He wrote that these people could be sterilized "so that society can be liberated from the economic and moral responsibility which it would otherwise have when faced with these children." ${ }^{\text {"52 }}$ The third category was "eugenic" and in a parenthesis the term race-hygiene was used. ${ }^{533}$ Ingebrigtsen defined the eugenics category as individuals who were connected with the social category and could certainly be expected to have progeny "as worthless as their origin." 534 The difference between the two categories is the expectation that deficient genes can be eliminated from the population and that the average health of the entire population can be bettered in the long run. ${ }^{535}$ The fourth and final category is the "criminal-political" which is similar to category number one, the "humanitarian." Here, Ingebrigtsen again described the exhibitionist who may not need to be incarcerated for prolonged periods if he can be castrated.

It is important here to reflect on the language used above. The use of the phrase "so that" is indicative of an "instrumental value expression" in which some action which is identified or controlled by the author gives certain consequences. ${ }^{536}$ Other "means-end" relations can be observed in such phrases as “...in order to...”, “...will bring about...."537 Means-end relations are "not conceived of as logically necessary but as potentially empirically verifiable." ${ }^{\text {"T38 }}$ They are subtle; they are without logic yet they infer scientific verifiability - at some unknown future point - making their use very powerful albeit indirect. In addition, they give us other information. These meansend rhetorical devices can locate values. As Klaus Krippendorf writes, the "hypothetical construct required to identify values in instrumental expressions further suggests viewing values as nodes in a network of asserted instrumental links." 539 Therefore, with some attention, one is able to trace these value-laden "nodes."

531 Ibid. I have translated "mindreverdige” as "inferior value”, "åndssvake” as "developmentally disabled" and "psykisk abnorme" as "mentally ill." I understand that the word "åndssvake" is no longer used in Norwegian speech but if used, has a negative connotation.

532 Ibid. (Emphasis mine.)

533 Ibid.

534 Ibid.

535 Ibid.

536 Klaus Krippendorff, “The Expression of Value in Political Documents” in Journalism Quarterly, 47 (1970), 514.

537 Ibid.

538 Ibid.

539 Ibid. 515. Krippendorff actually identifies a number of value assertive statements and an entire typology. Instrumental value expressions can be defined as $\mathrm{B}(1)$ : under condition $\mathrm{K}$, I leads to J; therefore $\mathrm{J}=\mathrm{V}$ where $\mathrm{B}(1)$ is the instrumental value expression, $\mathrm{J}$ and $\mathrm{K}$ are two further objects regardless of the author's identification, I is an object (action, behavior, situation, abstract conception or ideal) 
Ingebritgsen identified the practical results of sterilization as were seen in other countries that had passed such legislation. In his discussion of similar laws passed in the United States, Ingebritsen mentions both Indiana (1907) and California (1909) but dismisses them as essentially race hygiene, or perceived as race hygiene, because individuals were forcibly sterilized. By contrast:

The draft of the Norwegian law on sexual operations (sterilization) is not essentially race-hygienic in principle and cannot be characterized as forced through legal means. ${ }^{540}$

In retrospect, Ingebritgsen seems to have engaged in semantic sleight of hand here, since he must have known that the law would be "forced" upon those who fit criteria and were sterilized after legal procedure was followed. This is an example of a deft, almost unseen, breach of the Autonomy Theory of Law (ATL), a legal theory that theoretically insulates the Law from normative intrusion. ${ }^{541}$

While dismissive of the laws passed by individual states in the United States, he did take time to compare and contrast, in great detail, the Danish law passed in 1929 and the draft Norwegian law. The Danish law of 1 June 1929 had three categories or indications, i.e. humanitarian, criminal and political. The goal of that law was twofold, to

protect society against named sexual criminals (criminal-political indication) and in so doing save these potential sexual criminals from prolonged incarceration which would be the result of their sexual urges leading to (criminal) acts..... ${ }^{542}$

The Danish law, as interpreted by Ingebrigtsen, was compatible with eugenics and also applied to those with mental illnesses. There was also a large degree of "harmonization" between the draft Norwegian and the Danish laws. ${ }^{543}$

Next, Ingebrigtsen compared the Danish and draft Norwegian laws with regard to what is now commonly referred to as "informed consent"; in 1934, this dealt with who asked that the operation take place - the individual or a third party. He admitted that the Norwegian draft law goes somewhat further than the Danish law as regarded eugenic indications but, by the same token, the Norwegian law had more steadfast

with which the author identifies, and V is a value (goal, principle, standard, ideal) preferred, approved, presented or not. (Ibid., 517 -518.) Instrumental value expressions and other rhetorical devices have been mentioned throughout this work, as well as the semantic notion of the "ideograph", outlined in Chapter 2. (Please also see, Michael Calvin McGee, "The Ideograph as a Unit of Analysis in Political Argument” in, Jack Rhodes and Sara Newell (eds.), Proceedings of the Summer Conference on Argumentation (Annandale, Virginia: Speech Communication Association, 1998), 68-87.)

540 Aftenposten (p.m. Edition), January 3, 1934, 2.

541 The ATL, also called the Separability Thesis, will be discussed throughout Chapter 8.

542 Aftenposten (p.m. Edition), January 3, 1934, 2.

543 Ibid. 
limitations. ${ }^{544}$ And additionally, in contrast to the Danish law, the Norwegian law had a provision for the operation at the initiative of the Chief of Police. In general however, he argued that the two laws were compatible.

Between 1930 and 1934, Denmark had castrated 41 men and no women. The 41 men could be divided into three groups; 1 . those without a criminal record, 2 . those who had previously been adjudicated as sexual criminals and 3. those who had been adjudicated and had been sentenced to an indeterminate length of time for sexual crimes. ${ }^{545}$ From the first group, only one man had been voluntarily castrated; this was on 1 September 1930 involving a 63-year old homosexual who found that his urges had not subsided over the years and who thought that he might not be able to restrain himself in the future. From the second group, nine men had been castrated. The age range was 26 to 59, the average being 44.5 years of age. Four of the men had been adjudicated for exhibitionism, three for sexual behavior with boys, one for sexual behavior with a girl and one, a doctor, for indecent behavior with a male patient while the patient was under anesthesia. From the third group, individuals sentenced to confinement for an indeterminate time for sexual crimes, 84 people had detained and 31 castrated since 1925 pursuant to the Danish criminal law. The categories can be seen in the following chart.

Table 4.1: Number sterilized pursuant to the Danish sterilization law

\begin{tabular}{lllllll}
\hline & $\begin{array}{l}\text { From Psychopathic } \\
\text { Institution }\end{array}$ & $\begin{array}{l}\text { Dangerous } \\
\text { Criminals }\end{array}$ & $\begin{array}{l}\text { Developmentally } \\
\text { Delayed }\end{array}$ & Insane & Epileptics & Total \\
\hline $\begin{array}{l}\text { Number } \\
\text { Detained }\end{array}$ & 55 & 3 & 20 & 0 & 6 & 84 \\
\hline $\begin{array}{l}\text { Number } \\
\text { Castrated }\end{array}$ & 17 & 0 & 11 & 0 & 3 & 31 \\
\hline
\end{tabular}

An earlier Danish criminal law from 1925 had pertained to those who were "weak or (had) disturbed mental faculties." ${ }^{" 56}$ Leaders of institutional facilities were the first to take advantage of this imprecise language initiate the procedure. The bulk of the 84 detainees were "veterans" who had been already "dismissed" from society and were in state institutions. After castration, the 31 who were castrated were observed for between 6 months to one year. It was noted that they were "calmer" in their presentation, easier to be with in their work place and that the operation had produced results generally beyond expectations. ${ }^{547}$

544 Ibid.

545 Ibid.

546 Ibid.

547 Ibid. 
Of the 31 castrated, only one had been a recidivist and had been adjudicated three times for inappropriate behavior with boys, the most recent conviction in 1928. This 41 year-old man had been castrated on 1 February 1930 and was released on 1 June 1931. However, this individual was again interned for the same type of behavior after the castration, giving Ingebrigtsen the opportunity to say that the procedure was not entirely without limitations.

In addition to these 31, other Danish citizens who were institutionalized had undergone sterilization pursuant to paragraph 2 of the 1925 criminal law under the hybrid heading of "social-humanitarian" reasons. All of these individuals, both men and women, were developmentally delayed. Eleven men and 51 women had been sterilized. Danish state attorney Goll remarked that this "has been to the happiness of those operated on and a gift to the concerned public treasury." 548 While finances seemed always to be a concern for Goll as well as Ingebrigtsen, Goll did say that these additional people were sterilized with other considerations in mind, i.e. "so that their unrestrained sex-drive might not lead them to be blamed for crimes with lasting consequences." ${ }^{549}$ Guilt and the financial burden of unwanted children without fathers who might otherwise support them were the two sides to the rationale for sterilization.

Goll noted that the Danish law would be revised but the race-hygiene section of the law would not be affected. If the draft Norwegian law were to be enacted, it was his opinion that there "would be for non-criminal cases a certain degree of stretching [of the law] with regard to the application for permission for the sterilization." 550 Assuming that both Goll and Ingebrigtsen had an accurate working knowledge of the Norwegian law as it was and as it would become under the new law, this is a telling statement. We shall eventually meet this "stretching" of the law, not in theory but in reality, as it unfolded throughout the course of 1934. These men knew what was permissible and what would become a gray-area of practice under the new law. The implication is that they saw an advantage in the new law.

Aside from medical doctors, academic professionals became involved early on with the draft law just as did some attorneys and politicians had. Two individuals mentioned in the Ingebrigtsen article were Dr. Torp, Professor of Physiology in Oslo and Ragnar Vogt, Professor of Psychiatry in Oslo. As early as 1933, the Justice Department, the Norwegian Medical Director and the Medical Faculty in Oslo had solicited these two, along with Ingebritsen, for their input as to the generally known effects of castration. ${ }^{551}$ Many others took various positions on the draft law before and after

\footnotetext{
548 Ibid.

549 Ibid. (Emphasis mine.)“...for at den ubeherskelige kjønnsdrift...”

550 Ibid. (Emphasis mine.)

551 Aftenposten (p.m. Edition), January 3, 1934, 6. As of 22 February 1933. In a later article in the same newspaper, April 6, 1934, at 5, editors call the results from the sterilization of the developmentally disabled in Denmark favorable ("gunstige").
} 
its passage ${ }^{552}$, but Vogt and a Dr. Alfred Mjøen ${ }^{553}$, as well as Ingebritsen, were most vociferous in their support of the measure.

What were the "consent" provisions in the draft law? A third party, someone other than the patient could give consent for the procedure and this was provided for in paragraph 3. Despite the fact that Goll had said that one could be justified in foreseeing that if "the Norwegian proposal becomes law [it] can have a larger reach than the Danish law as regards the mentally retarded, institutionalized individuals with an abnormal sex drive and sexual repeaters....”, there would still be safeguards to be sure, rules put in place which doctors had missed in the past. ${ }^{554}$ Ingebritsen noted that the pending law could not entirely prevent the birth of defective individuals but it could help in elevating the average "quality of life" and in a difficult social and political time, how could one regret this consequence? Ingebrigtsen's last sentence in this extended article is of interest.

A genetic approach with regard to these questions is, in the meantime, an entirely correct assessment. Research has gone a long way in giving us insight into the prevailing laws of inheritance, which must be the assumption such that one may - if even only negative results, i.e. exclusion of genes - anticipate a more or less regular result. ${ }^{555}$

Several monumental assumptions are at work in these two short sentences, just as in the Indiana law of 1907. The first assumption was that society had a problem, i.e. "these questions" involving abnormal humans, and the second assumption was that activity based in science, i.e. "laws of inheritance", with the help of the Law could solve the problem.

The "problem" was framed as a heady rhetorical brew including the expenditure of public finances, crime and crime prevention and uncontrollable lust. Public finances, whether lacking or not, were assumed to be lacking and paid for through taxation of the hard-working "normal" citizens of the country, be they Danes or Norwegians or Americans. Those who had direct contact with criminals, i.e. the police, attorneys and courts as well as in the church community, perceived crime as an ever-

552 In 1934, one can read editorials in the same newspaper about the impending law from Dr. Johan Lofthus (2 May 1934 - sterilization law), Dr. Henrik A. Th. Dedichen (2 June 1934 - crime and punishement), Dr. Sofus Widerøe (22 June 1934 - Hitler’s sterilization law), Attorney Håkon Benneche (12 July 1934 - crime and punishment), and Police Chief Fr. F. Kaltenborn (18 July 1934 - criminal institute in Vienna). These are only the articles written by experts in the editorial section.

553 Dr. Alfred Mjøen was a major figure in the eugenics movements in Norway and we shall meet him shortly. It would be interesting to know why he was not also asked, along with Torp and Vogt, since he obviously had an opinion on the subject. My impression is that, although Mjøen claimed scientific credentials and did what passed for science at his Vindern laboratory, he was not taken as seriously as those who worked within the academic arena.

554 Aftenposten (a.m. Edition), January 3, 1934, 2.

555 Ibid., 6. 
increasing problem. The new, reified science of genetics gave a "correct" approach to this societal problem. Furthermore, research supplied an empirical basis and thus a "rational" or "reasonable" approach.

Current scientific thought allowed these experts to presume that, if society could just exclude negative genes, then the outcome would be predictable, i.e. the quality of life would be improved for all. The importance of genes and chromosomes was the biological cutting-edge discovery of the moment. Dr. Ingebritgsen, for example, was clearly aware of the work of American scientist/geneticist, Thomas Hunt Morgan, since he had been awarded the 1933 Nobel Prize in Medicine for his work on chromosomes. Numerous Norwegian scientific luminaries, including both Professors Ragnar Vogt and Otto Mohr - who had nominated Hunt for the award as early as 1923 - were also aware of Hunt's work. ${ }^{556}$

Two months after Ingebrigtsen's lengthy article, Cabinet Minister Sunde decided to put forward the sterilization law in the Storting. ${ }^{557}$ The draft law, built upon the Criminal Law Committee's work, gave several ways sterilization could be permitted. First, the Medical Director, on the advice of an expert, had the power to give permission for sterilization or castration. The person him or herself might also ask for the operation when "the request has a worthy reason." 558 If the person requesting the operation was less than 21 years old or was mentally ill or developmentally delayed, the consent of the person's juridical guardian or a specially named trustee was also required. In "certain cases" only the consent of the guardian would be necessary, i.e. cases concerning the mentally ill or the developmentally delayed. These cases had to meet two requirements. There had to be no hope of health or "essential" or "meaningful" improvement and there was reason to suppose that the person would not be in a position to become employed or to care for any children he or she might have or that an abnormal mental condition or a considerable bodily defect might be passed on to the children or that, due to some abnormal sex drive, s/he would commit a sex crime. ${ }^{559}$

Exactly how one could be sure there might be no hope of improvement or how an "abnormal mental condition" or a "considerable bodily defect" would or could be measured was not addressed. ${ }^{560}$ In addition, the Chief of Police was given the power to propose these operations for persons meeting the above criteria. Further, the administrator of any jail, workhouse, institution that cared for these persons or edu-

556 Aftenposten (p.m. Edition), March 2, 1934, 2.

557 Ibid.

558 Ibid.

559 Ibid.

$\mathbf{5 6 0}$ Leaving the law in terms of general principles is standard practice in Norwegian law. The particular definitions and rules are left to administrative authorities (forskrifter). I am thankful to Prof. Sætnan for this input. What this seems to do - as compared to the common law countries - in effect, is to allow the law to change as norms change without a long and costly mudicial process. 
cated them could also make the request if the guardian or trustee was in agreement. The Medical Director could also give consent if the person was less than 21 years old, mentally ill or developmentally delayed. In that case, the Director also needed the consent of a council of five members with the Director as Chairman. From a procedural standpoint, the Chief of Police and the Administrative Director of an institution were given a great deal of latitude. Even though it might seem as if a better situation was used when the Medical Director made a decision and a second form of consent was needed from a 5-member group, that group was still headed by the same Director, which makes for a conflict of interest situation.

The proposal did not make any changes to the existing law that allowed a doctor, on his or her own initiative and with the consent of the patient, to sterilize or castrate the patient as long as there was a medical or "other" reason for the operation that was lawful under the provisions of the new law. Although the new law did not advise forced operations, sexual criminals could voluntarily submit to castration after serving his or her sentence. It was anticipated that through this method, preventive detention would in most case be done away with. ${ }^{561}$

Ingebrigtsen's Afterposten assessment of the new sterilization law gives a glimpse into what he and others believed would be the effect that science could have in society. He used a means-end rhetoric that essentially circumvented verification. Nonetheless, we can locate the values in that discourse and those values were to "liberate society from the economic and moral responsibility which it would otherwise have when faced with these children." ${ }^{562}$ Ingebrigtsen's style was more nuanced than, for example, that of Dr. Jørgen H. Berner, who bluntly asked what do when "we have 100 idiots [who] cost society so much money [and] for the same amount of money we can support 200 healthy children." 563 As noted above, Krippendorf writes, that by identifying values/norms through looking at instrumental expressions, such as Ingebrigtsen's, we can view these values/norms as nodes in a network of asserted instrumental links. This also supports the idea that articulations that are made - and remade through use of the Jasanoff fields are important evidence of invisible values/norms and their inclusion in law.

Eventually, the number of women and men who were sterilized pursuant to Norway's 1934 sterilization law reflected the same gender imbalance as Allison Carey saw in the case of the United States. From the period 1 June 1934 until 29 December 1942 and from 9 May 1945 to 31 December 1977, there were 46,596 applications for steriliza-

561 Aftenposten (p.m. Edition), 2 March 1934, p. 2. Preventative detention (sikring”) is a Norwegian concept which can mean that a prisoner continues in confinement after he or she has served a sentence. This would most likely take place with regard to violent psycho-sexual persons; in the United States this type of detention would be a civil legal process and not a criminal one.

562 Aftenposten (a.m. Edition), January 3, 1934, 1 continued to 6.

563 Aftenposten (a.m. Edition), August 29, 1934, 2. 
tion in Norway. During the Nazi occupation itself, from 29 December 1942 until 8 May 1945, there were a total of 570 applications. ${ }^{564}$ Between 1934 and 1977, the number of women and men applicants under the 1934 law was 32,411 and 14,055 respectively. More than twice the numbers of applications were made by or on behalf of women than men. That imbalance increased to a three-fold difference under the 1942 Nazi inspired sterilization law. Applications by Norway's Medical Director during this period were 281 for women and one for a man. ${ }^{565}$

The number of sterilizations that were actually carried out pursuant to the application procedure was $86.22 \%$ of the total number of applications (women) and $97.20 \%$ (men) under the 1934 law, 91.28\% (women) and 74.77\% (men) under the 1942 law, and $86.83 \%$ (women) under the Medical Director's application. ${ }^{566}$ It must be said that Norway sterilized fewer people than either Sweden or Finland until 1966-1968 when the number of sterilizations in Norwegian hospitals increased dramatically, primarily as a matter of birth control. This continued until the law was changed in 1978 allowing "self decided" abortion until the third month of pregnancy.

Norway did not have the "flood" of immigrants that came to the United States prior to 1907. Nonetheless, it had its own variety of those perceived, as "other" and this group was the focus of sterilization advocates. These were the "taterne" who were an ethnic group who had adopted various ways of life, both settled and mobile, but almost always on the margins of Norwegian social and cultural life. From the middle of the 1800s the DNK had worked with “the travelers.” Norway's Christian groups "showed a special interest for this minority and can be seen as what we might call 'moral entrepreneurs' in this area." ${ }^{\prime 67}$ During this period, the nation-building phase of Norway's history, the idea of a "real Norwegian” was clearly connected to

more or less romantic pictures of the farmers' life style and culture, such that it became constituted and cultivated through the building of folk museums, through folk music, folk tales, farmer experiences, traditional farmer clothing, village history books and the like. ${ }^{568}$

In all of these areas, there was simply little place - or very little opportunity - for the ethnic minorities mentioned above to fit into society - should they want to - especially if they were labeled as "transient" or "vagrant."

Religious structures as well as the governmental structures intersected to consider this group as a subject for sterilization. In addition, if we look back at the interwar period in Norway, two well-known medical doctors, Ingeborg Aas and Johann

564 Per Haave, Sterilisering av tatere, 1934-1977: En historisk undersøkelse av lov og praksis (Oslo, Noreges Forskingsråd, 2000), 152.

565 Ibid.

566 Ibid., 154.

567 Ibid., 20-21.

568 Ibid., 21. 
Table 4.2: The number of applications for sterilization, 1934-1977. Men and women of tarter ethnicity (Haave's Table 6.10)

\begin{tabular}{llll}
\hline & Women & Men & Total \\
\hline 1934-law & 113 & 20 & 133 \\
\hline 1942-law & 17 & 2 & 19 \\
\hline Medical Director* & 3 & - & 3 \\
\hline Total & 133 & 22 & 155 \\
\hline
\end{tabular}

* Application made by Medical Director, 1.1.1943-8.5.1945

Table 4.3: Applications for sterilization, consented and completed applications under the 1 June 1934 law with respect to men and women of tater ethnicity (Haave's Table 6.11)

\begin{tabular}{lllllllll}
\hline \multicolumn{3}{c}{ Women } & \multicolumn{1}{c}{ Men } \\
\hline & $\begin{array}{l}\text { Applica- Con- } \\
\text { tions }\end{array}$ & $\begin{array}{l}\text { Total } \\
\text { sents }\end{array}$ & $\begin{array}{l}\text { Carried Out Percent } \\
\text { of the number of } \\
\text { applications }\end{array}$ & $\begin{array}{l}\text { Applica- Con- } \\
\text { tions }\end{array}$ & $\begin{array}{l}\text { Total } \\
\text { sents }\end{array}$ & $\begin{array}{l}\text { Carried Out Percent } \\
\text { of the number of } \\
\text { applications }\end{array}$ \\
\hline$\S 3,1$ & 63 & 61 & 50 & 79.4 & 9 & 8 & 7 & 77.4 \\
\hline$\S 3,2$ & 20 & 10 & 18 & 90.0 & 6 & 6 & 4 & 66.7 \\
\hline$\S 4$ & 30 & 28 & 26 & 86.7 & 5 & 5 & $4 *$ & 80.0 \\
\hline Sum & 113 & 108 & 94 & 83.2 & 20 & 19 & 15 & 75.0 \\
\hline
\end{tabular}

* Sterilization also took place on five (more) men, but instead of being sterilized, they were castrated.

Scharffenberg, had already raised the question of sterilization of the tarterne in 1929. Scharffenberg, who we have mentioned above, played many roles during the interwar period; he was, from 1919 until 1940 the doctor of a Penitentiary and from 1922 was a Chief Resident at the Oslo mental hospital. ${ }^{569}$

The number of taterne who were sterilized under these laws is a bit more difficult to assess than the general population. As a percentage of the total number of people sterilized, they constituted only about a very small portion. If we compare the number of sterilizations on non-"taterslekt" ${ }^{\text {"70 }}$, the total number that were carried out between 1935 and 1950 per 1000 citizens in Norway was 2,061. This is from a total

569 Ibid., 67. Scharffenberg held the second position from 1922 until 1941 when, under Nazi occupation, he was removed.

570 Tarter ethnicity. 
population of 3,265,126 people, giving us a number of 2.87 per 1000 citizens. Between 1935 and 1977, 155 applications for sterilization of tarter ethnicity were made. ${ }^{571}$

How many of these applications were carried out? Haave gives us the following information.

From these two tables we can see that the percentage of applications from tarter women that were carried out was consistently greater than that for men. But this still does not give us a comparison between applications carried out for tarter persons and non-tarter persons. Haave does, however, give us information about the number of vagrant women who were sterilized as compared to all women in Norway who were born between the years 1900 and 1959 and sterilized under the 1 June 1934 law.

Table 4.4: The number of women in the population sterilized with reference to the 1 June 1934 law on sterilization and who were born between 1900 and 1959 (Haave's Table 6.10) (572 $^{5}$

\begin{tabular}{llllllllll}
\hline & \$3 first section & \multicolumn{2}{c}{$\$ 3$ second section } & $\$ 4$ & \multicolumn{3}{c}{ Total } \\
\hline & Number & Per 1000 & Number & Per 1000 & Number & Per 1000 & Number & Per 1000 \\
& & 16,32 & 15 & 5,97 & 21 & 8,36 & 77 & 30,64 \\
$\begin{array}{l}\text { Vagrant Women } \\
(\mathrm{N}=2.513)\end{array}$ & 41 & & & & & & & \\
\hline $\begin{array}{l}\text { All women } \\
(\mathrm{N}=1.693 .244)\end{array}$ & 27.946 & 16,50 & 1.087 & 0,64 & 813 & 0,48 & 29.846 & 17,63 \\
\hline
\end{tabular}

Here we can see that the number per 1000 of vagrant women that were sterilized under all three sections was nearly double the number for all women, i.e. 30.64 compared with 17.63. After World War II, the number of sterilizations of men and women under the 1 June 1934 law followed a pattern similar to that described by Allison Carey in the United States. The type of body that was impacted the most, after the introduction of birth control, was the poor female body. ${ }^{573}$

Several groups made note of the taterne and their lifestyle but it was the work of what became known as the Norsk misjon blant hjemløs (NMBH). Originally the group was known as "The Association to fight against the Vagrant" and was a "Christian philanthropic group" and its first efforts were at assimilation of the taterne. ${ }^{574}$ This was similar to how various religious and charitable groups in the United States tried to assimilate Native American children. The NMBH group made several assumptions. They believed that a "mobile lifestyle" was more or less criminal and the life style itself was at least partially biologically pre-determined. In addition, the background

571 Per Haave, Sterilisering av tatere, 165.

572 Ibid., 168. This table is mistakenly labeled and should be Table 6.12.

573 Ibid., 162.

574 Ibid., 180. 
of the group had "an association with the politics of criminality and the racial hygiene viewpoint." $" 575$

While the NMH made the taterne a focus for its work it was psychiatric institutions that led the way in submitting applications for all vagrants who were sterilized. The NMH led the way in terms of applications for young vagrants, i.e. vagrants between the ages of 17 and 24. During the emphasis on human rights in the 1980s the role of various groups in their use of the 1934 sterilization law was scrutinized by the Storting; remuneration was paid to those still living for having been sterilized and both right- and left-wing governments apologized to them, as did the Norwegian Lutheran Church.

Per Haave points out that Norway's treatment of the tarterne "did not happen in an empty room." ${ }^{576}$ Many things could be said about different institutions that dealt with the tarterne. I will focus here on just one, the NMH and on two facets of their work. The first facet is how this group believed itself to be doing, at the very least, philanthropic work for the less fortunate. In 1931, Ingvald B. Carlsen, who was the NMBH General Secretary from 1918 to 1935, said in an informal radio lecture that:

It's the Christian feeling of responsibility (or the human feeling of solidarity) that tells us that these are human beings and we must try to give them a sense of human worth. ${ }^{577}$

But despite this, the goal of the NMH was always twofold, to gain social control over the tarterne as well as to provide assistance to them. A private Vagrancy Committee was set up in 1933 which set into motion more repressive policies including registration of vagrants, their fingerprinting, charting of prisoners residences along with interning "asocial" vagrants and sterilization of "the lowest level of vagrants." 578 But the rhetoric of care, in this case - Christian rhetoric - is not unlike the rhetoric of the progressive movement in Indiana. In many cases, the progressive movement allied itself with American churches, mostly protestant, and had identical concerns as this NMBH in Norway, albeit to different minority groups.

Just as 1907 in Indiana, there were powerful professional men in Norway who represented the two institutions of medicine and law whose interests intersected with the interests of political parties in Parliament. Although fewer attorneys and medical

575 Ibid. "Bakgrunnen var en orienteringmot kriminalpolitiske or rasehygieniske synspunkter; grupper med mobile livsformer ble antatt å være mer eller mindre kiminelle, og deres levemåte ble former som delvis biologisk bestemt."

576 Per Haave, "NS-Regimets 'taterpolitikk' - en minoritetspolitikk i utakt?” in Per Ole Johansen (ed.), På Siden av Rettsoppgjøret (Oslo: Unipub Forlag, 2006), 180, (my translation).

577 Ibid., 185.

578 Ibid., 187. Omstreiferkomiteen, “...foreslo komiteen en omsteifer- og løsgjengersentral, registrering, en trykt fortegnelse over omsteifere, kartegging av innsattes hjemstavnsforhold samt internering av 'utpreget asosiale omstreifere' og sterilisering av 'de laveststående omsttreifere'.” 
doctors were elected to the Storting than in the case of Indiana, this was likely a function of the relative prosperity of the two countries, even accounting for the passage of time. Even in 1934, Norway had not yet "caught up" with where Indiana had been in 1907 in terms of the number of doctors who could leave a practice for politics. ${ }^{579}$ Another possible explanation was the type of education needed in each country to identify oneself as a "doctor." "Quackeri” (charlatanism) in Norway was a major issue in 1934 and, although the same phenomenon appeared in Indiana in 1907, the state Pure Food and Drug Law, passed in 1907 as a precursor to the national law, helped to relieve that situation.

On 22 August, Aftenposten reported on the Jurists' meeting that had begun on the Thursday the $16^{\text {th }}$ in the packed Aula Auditorium at the University of Oslo. ${ }^{580}$ Thematically, the issue of the attorney-client privilege and protection of this right was to be discussed but another major impetus for the meeting was that the group was celebrating its $200^{\text {th }}$ year of existence. Various attorneys and dignitaries attended including Professor Fredrik Stang (1867-1941), Supreme Court member Hagerup Bulls and attorneys from Denmark, Sweden, and Finland. King Håkon VII (1872-1957) entered the hall at about noon and Professor Ragnar Knoph (1894-1938), who had been nominated for the Nobel Peace Prize four years earlier by Norway, gave the plenary session speech on "the protection of the personality." 581

Jurists in Norway were facing not only fundamental epistemic uncertainty about the nature of law itself as revealed in Scandinavian debates about legal realism which stretched into the 1970 s - but practical problems also concerned them. The pace of civil litigation had been increasing in Norway and courts were congested, especially at the appellate level. Lawyers were aware that Norway's civil procedure was in need of revision. This issue, among others, had been up earlier in the year at the annual meeting of jurists in one of Norway's northern-most cities, Troms $\emptyset$. About 40 jurists ${ }^{582}$ from around the country plus 3 chief administrative officers, judges from rural districts, the Mayor of Troms $\varnothing$ and various authorities as well as members of the Trial Lawyers Association attended the meeting. ${ }^{583}$ While a number of topics occu-

579 Please see, Jonathon Moses, Norwegian Catch-Up: Development and Globalization before World War II (Aldershot and Burlington: Ashgate, 2005).

580 Aftenposten (p.m. Edition), August 123, 934, 2. The Aula is in use today and is also a tourist attraction. It contains paintings on the walls by the artist Edvard Munch and is used for awarding Nobel prizes as well as for doctoral defenses, public lectures and concerts.

581 In common law countries the "protection of personality" is seen as the basis for tort law and rights of privacy.

582 In 1934, various types of attorneys existed in Norway. The location of knowledge in a society has been addressed by lawyer and sociologist Vilhelm Aubert (1922-1988). He also wrote his PhD dissertation on the subject of attorneys, their class origins, etc.

583 Aftenposten, (p.m. Edition), January 5, 1934, 1. Attendees included sorenskrivers Bonnevie and Falch, overrettssakførerne Falck, statsadvodkat Fjalstad and Oslo Chief of Police Jensen. 
pied the attention of the attendees, the appellate system in Norway was under review and was subjected to heavy criticism at this meeting. As Vilhelm Aubert later noted, between 1815 and 1950, "the number of attorneys increased by a factor close to 20" while the "number of judgeships was not more than doubled." 584 Sorenskrive (Notary Public and lower-court Magistrate) Bonnevie wondered if the lower courts needed a new appeals process. ${ }^{585}$ And, Attorney Falch hinted at the possibility of a circulating Court of Appeals that would travel throughout the country. ${ }^{586}$

One of the most significant legal reforms that were considered in the months of 1934 in the Norwegian media was that of abortion. Eight months after the jurists' meeting referenced above, state's attorney Sunde and a good number of the same jurists convened in Oslo to consider the issue. An extensive article in the Aftenposten summarized the speech made by Swedish Cabinet Minister K.J. Schlyter who was featured along with Norwegian state's attorney Sunde. ${ }^{587}$ Schlyter, a respected Swedish jurist, who had published a complete collection of old laws as well as participating in the modernization of Swedish law, spoke on induced abortion and its criminal penalties. ${ }^{588}$ He began by quoting statistics from Sweden for 1922, 1926 and 1930 that had been gathered by Associate Professor John Naeslund and governmental Bureau Chief K.A. Edin. Their research showed that 15,299 abortions had been performed in Sweden in those particular three years within all hospitals. ${ }^{589}$

The national population of Sweden during those years was 5,987,520 (1922), $6,074,368$ (1926) and 6,142,191 (1930). ${ }^{590}$ During these three years, about 15,299 abortions were performed; 359 were for "medical" indications and 502 for "criminal" indi-

584 Vilhelm Aubert, Professions in Norwegian Social Structure, 254. The number of fathers' of attorneys who themselves were attorneys, businessmen or other academics was in the process of decreasing while the number of attorneys whose fathers were "functionaries", farmers, artisans and workers was increasing. Ibid., see Table II.

585 Ibid.

586 Ibid. His "hint" was specifically detailed enough to include the fact that it should be composed of lower court judges and a Presiding Judge and proposed a procedure whereby the court might not become overburdened, i.e. letting the Presiding Judge streamline some litigation. In 1915, two new important codes had already been been enacted by the Storting - the Code of Civil Procedure (Tvistemålsloven av 13. August 1915 nr. 6) and the Courts Code (Domstolloven av 13. August 1915 nr. 5) but this does not seem to have offered any relief in his opinion.

587 Aftenposten (p.m. Edition), August 24, 1934, 5.

588 Please see, Jan-Olof Sundell, "Karl Schlyter: A Swedish Lawyer and Politician” in Stockholm Institute for Scandinavian Law 40 (2000), 505-514.

$589 \mathrm{Ibid}$. This number is very large when one compares it to the number of abortion laws were liberalized in 1938. For example, in 1939 the number of reported legal abortions in Sweden was 439. Please see, http://www.johnstonsarcchive.net/policy/abortion/ab-sweden.html, accessed July 5, 2009. For an overview of abortion liberalization in Europe, please see Christopher Tietze, "Abortion in Europe" in the American Journal of Psychiatric Health, 57 (1967), 1923-32.

590 Please see, Statistiska centralbyrå at, http://www.scb.se/Pages/List_25377.aspx last accessed on July $5,2009$. 
cations. Among these 502 women who had abortions, 38, or 7.6 percent died. Of the remaining women ${ }^{591}, 3,182$ developed fevers and 121 or 2.8 percent $^{592}$ died. In 1930, statistics showed a total of 10,445 abortions and 95,000 live births. This meant an average of 10.9 abortions for every 100 live births. ${ }^{593}$ But in Stockholm alone, this rate increased significantly to 25.6-33.8 for unmarried women and 15.8 for married women. Edin indicated that he believed the number to be "at least" 30 abortions for every 100 live births in Stockholm. In Germany, the number was said to be 33 per every 100 births. Scandinavian women were not being seen by competent medical doctors or midwives for any number of reasons including the abortion law and perhaps as many as 100 women died every year because of this. ${ }^{594}$

This meeting, which took place after the passage of the sterilization law, demonstrates the on-going articulations between the medical and legal institutions as regards body-law. This is important because the discourses about the revision of the then-current abortion law in Norway clearly over-shadowed the discussion of the sterilization law in 1934 if one considers frequency of discussion in the Norweigan press.

The bodies of those with disabilities and the bodies of criminals carried no particular power vis-a-vis the two major institutions of law and science, but we might expect that the bodies of women would be of some concern since the national birth rate was ostensibly a problem. ${ }^{595}$ There was also a concern that women themselves have a degree of participation in decisions regarding reproduction, although this idea is also tied, as we see below, to ideas of the nation's legal "modernization."

591 Aftenposten (p.m. Edition) August 24, 1934, 5. The reporter who wrote this article was not specific as to what "of the remaining women" referred to.

592 If we assume that 121 women out of 3,182 died, this gives us 3.8\% not 2.8\%.

593 Aftenposten (p.m. Edition) August 24, 1934, 5.

594 Ibid. The issue of abortion had previously been addressed many times in Oslo newspapers, but in June, in the Aftenposten, a signed letter to the Editor was printed. The signators were Dotors Kristen Andersen, Hj. Schelling, Kristen Skajaa, Sofus Widerøe, Supreme Court Judge Thomas Bonnevie, Carl Hartmann, Attorney J.M. Lund and Harold Nørregaard. The question this group posed was whether or not abortion should be permitted if indicated for "humanitarian" or "social" reasons? The letter provided some guidelines; women would be required to apply for the abortion and to meet with three advisors, i.e. the hospital physician, the city or district doctor and a third doctor named by the county commission, all of whom had a duty of confidentiality. (Aftenposten (p.m. Edition), June 29, 1934, 1.) The authors of this $\$ 245$ letter - $\$ 245$ of the criminal law forbidding abortion - began their argument with statistics. In Germany for the year 1924 there had been over 800,000 abortions. In Oslo's Ulleval Hospital, the number of abortions from 1920-1929 was said to be around 3,800. (Ibid., 2.) The doctors mentioned that they themselves had no wish to be at odds with the criminal law; it was their desire to have an abortion law passed by the Storting that would be punishment-free but yet not imply some moral acceptance of abortion itself. Irrespective of the fact that abortion was to a greater or lesser degree morally reprehensible, the only way to free people form the abuses of "quack-doctors" was to allow legitimate doctors to do the procedure without fear of punishment, or so this group reasoned. 595 Aftenposten, (a.m. Edition), May 9, 1934, 3. 
For Schlyter, whose support for the changing of laws against abortion seems to be rooted in practicality, there appeared to be "quite a large degree of agreement" on the issue - at least in his social and work circles. He said that the reasons which "can be summarized as ethical and eugenic, should give a right to the termination of pregnancy. There need be no other more exhaustive motivation." ${ }^{596}$ He cited cases of rape or incest, or where the mother or father was mentally ill, as obvious candidates for abortion but also mentioned the fact that should a young woman become pregnant and not be afforded the option of an abortion she might become dependent on the man for economic reasons.

Norwegian Medical Director Heitmann was quoted as saying that he would make use of the expression "a violation of a woman's sexual freedom" instead of an offense (crime) against a woman's sexual freedom "so as not to tie the right to abortion to a certain criminal law's perhaps antiquated chapter on sexual offenses." ${ }^{297}$ Comparing the proposed Norwegian law to the equivalent Swedish and Danish laws, he said that Norway's law was more like the Swedish law on abortion but with a goal similar to the Danish. ${ }^{598}$

Schlyter then discussed the various "indications" which had been proposed as reasons for an abortion. As to "eugenic" indications, he was very clear about the legal wording for abortion that had been proposed. He said that the "eugenic reasons" for abortion "agree with" the corresponding "eugenic indications" in the new Norwegian and Swedish laws regarding sterilization. ${ }^{599}$ Where there is a difference between the two laws - in accordance with the first draft where a reason for sterilization was the transmission of a dangerous bodily sickness - Schlyter preferred to follow the Norwegian law. As regarded the "social" indications in Sweden that existed as a reason for abortion, Schlyter wanted first to rescind the current contraception law, which stood in the way of on-going work on anti-conception methods. "We" are "late-comers" to the modernization of law, he said, and despite having a welfare state and having the information, all types of distressing situations still existed. ${ }^{600}$

Schlyter's idea for the reform of abortion laws also had connections with the new sterilization law. He commented that it had been suggested that, "with the new Norwegian sterilization law as a model", one could reduce the explanation needed for an abortion and that a woman herself could simply ask for the abortion based on a "reason which could be respected." Schlyter thought it impractical to detail all of the reasons that could be given for an abortion. He reasoned "Life is so varied and

596 Aftenposten (p. m. Edition), August 24, 1934, 5.

597 Ibid.

598 Ibid.

599 Ibid.

600 Ibid. 
richer in situations than any theory." ${ }^{601}$ In a choice between the previous suggestion and some other language, Schlyter would have chosen language such as "for highly respectable reasons" for the Norwegian sterilization law. ${ }^{602}$ But it is clear that he also has some concerns about the language of "respectable reasons" becoming so vague as to encompass too many situations not really worthy of respect. Could a law with this type of wording become meaningless because of its vagueness? As with all drafting of legislation and legal codes, the wording must be detailed enough to mean something and produce the result that is wanted and nothing more - or less. ${ }^{603}$

Schlyter discussed the meaning of "need" in which he placed an emphasis on "economic" need. Should a woman be "condemned" to a pregnancy despite many other births and difficult work as the provider for the children? This type of situation could be similar to the "medical" indication if the mother's health were damaged as a result of carrying the pregnancy to term. But various types of distressing situations in a family could be imagined - for example, when a seaman returns home after a "long" voyage, i.e. more than nine months, and finds his wife pregnant. As the speaker said, we "obviously cannot have a common legal principle that allows for abortion in cases of marital unfaithfulness." 604

On the other hand, Schlyter reasoned, should a family be allowed to throw a daughter out of the house "onto the street" when it becomes known that she is pregnant - and unmarried? It is possible the only option for her in that situation would be to make a living through prostitution. Often it was the fate of young women who approached a doctor for an abortion and were refused that they went from the doctor's office "into the ocean." Was this not really a "medical" indication or at least an "expanded" medical indication? ${ }^{605}$ But he could not accept abortion for unmarried women as a general rule. And, he queried, what if the woman seeking an abortion is a teacher or a nurse? Which hospital supervisor would permit a woman to work as a nurse if she had a child? Obviously, there were societal norms that pertained to women at this time who worked in hospitals or classrooms, i.e. that they be unmarried and childless. ${ }^{606}$

This was neither the first nor the last time that legal reform of abortion laws in Norway would be considered. However, it is significant that it, rather than the sterilization law, was considered more seriously in the pages of both the political right and left media. A hierarchy of bodies was at stake, some more important than others. The

601 Ibid.

602 Ibid.

603 Ibid.

604 Ibid.

605 Ibid.

606 On August 25, 1934, the second half of the Schlyter's summary was printed in Aftenposten. One of leading discourses regarding women during 1934 was the ability of married women to continue working as teachers. Another discourse was the position of young girls who worked as "mothers' helpers." 
issue of abortion for women will be revisited in Case Two herein, where yet another dynamic will be investigated, one that proceeded at a slower pace but surfaces when the ideographs, social movements, and rhetorical framing bridgeworks are examined.

\subsection{Norwegian Parliamentary Masterframes: Legislating for National Health}

While the major discursive masterframe in Indiana was to legislate "against sin", the major discursive masterframe in Norway was to legislate "for health." This is discussed here with reference to the transcript from the committee meeting where the sterilization law was debated.

The "healthy body" rationale was seen in Norway just as in Indiana but the emphasis on sin was not so obvious in Norwegian media. Norway greeted exhibitions from Germany, and one entitled "Healthy mothers - healthy people" made its way to Oslo in March 1934. Not only was this exhibit brought north but it was also welcomed by members of the elite, including members of most powerful political institutions, i.e. the Royal Family (HRH Håkon VII), legal (States Attorney Sunde), and scientific (Medical Director Heitmann). Members of powerful social institutions also welcomed the exhibit. Marie Michelet, the leader of one of the largest women's group in Norway the Norwegian Housewives Association (NHF) and her lieutenants made an outing to the exhibit during their national convention, also held in Oslo. We find that at least two other national women's organizations had also made the same decision to visit the exhibit. ${ }^{607}$

During the autumn and spring of 1907, the focus of politicians in Indiana was first, on the election of the Governor since this determined the party-affiliation of the Speaker of the House. Representative Emmett Branch, who was eventually elected Speaker of the House, determined which bills would ultimately be considered since they depended a great deal on the Speaker's assignment to a specific Committee and the work of that Committee. The success or failure of a particular bill also depended on exactly when the Speaker put the measure to a vote. Rep. Branch was, in essence, the "switch" 608 for a legislative motor, someone who could turn a proposed bill "on" or "off."

607 Aftenposten (p.m. Edition), March 10, 1934, 7. The other two groups were the "Hjemmenes Velslandsforbund og Norges Røde Kors landsforening” (HVF and NRKF).

608 Reporter Blodgett often referred to the Speaker's platform as "the switch" and, amid numerous cartoons alluding to "special interest" lobbyists, announced that the "Guardians of the Switch" were more "restless" than usual on 7 March 1934 near the end of the session. As Blodgett wrote, "They are afraid that something of benefit to the people instead of the corporations and whisky element will get by them." But Blodgett also gives insight into the actual machinations that the Legislature witnessed. 
In Norway, where coalition building was more the model than was rule by a single party as in Indiana, the process was somewhat different. Many issues were of concern to the Storting including forced sales of businesses and farms, sale of effective or dangerous medicines, criminality - even whether or not women should be allowed to become priests in the Norwegian national church. ${ }^{609}$ Suffice it to say that, based on the space given to such types of stories in major Norwegian newspapers, the Storting was more concerned with these matters than with the proposed sterilization law. In addition, unlike in Indiana, we have the actual printed record of the Committee Meeting where the sterilization proposal was debated and it is to that meeting that I turn in this section.

On 9 May 1934, a little after noon, a Storting Committee took up the matter of the Report from the Justice Committee on the proposed sterilization law. President Eiesland called the Committee to order and the Chair of the committee was Bjørnson (Bondepartiet, B). Members who spoke about the bill were Bonde (SP), Bonnevie (Ap), Fjalstad $(\mathrm{H})$ and Cabinet Minister Sunde. In all, this Committee handled 8 items that afternoon, of which the sterilization law was number seven and it did so in 2 hours and 10 minutes, or, on average, it considered each matter for about 15 minutes.

The persons who spoke on this record were a unique set of individuals elected in 1934 and serving until 1936. Perhaps, the most interesting was an engineer, Gjert Edvard Bonde, from Bergen, the sole representative of the Society Party in the committee. He was one of two substitutes ${ }^{610}$ for the actual representative, Bergen sociological author and founder of the Society Party, Bertram Dybwad Brochmann (18811956) who had been unexpectedly elected in late $1933 .{ }^{611}$ The Farmers' Party was the

Sometimes when the clouds were the darkest and the air was heavy with gloom, and the Guardians of the Switch felt like going out to get a drink but were afraid to leave, Mr. Floyd Wood would enliven things with his famous song:

Carl Wood he had a little gas bill

Sam Murdock he laid it on a shelf

And every time it tried to move

It spanked its little self.

("Right in Among Legislators." Indianapolis News, 8 March 8, 1907.) What this appears to say is that Speaker Branch and his subordinates had to literally stay in place in order to defeat bills that the Hanley administration did not favor.

609 The last issue failed by one vote but was revisited again in the 1970s. In the translated transcription of the debate at Appendix E, Bjørnson makes mention of his vote for women priests. This gives a clue as to how fluid "progressive" politics was in Norway as well as in Indiana.

610 Although not elected, Bonde would substitute for Dybwad when he was unavailable.

611 The other substitute ("suppleanter") from the Samfundspartiet, also from Bergen, was a Resident Chaplain ("residerende kapellan"), Hans Bauge. http://exxtweb3.nsd.uib.no/data/polsys/Index. cfm?ArkivNr=18\&Institutionsnummer=1...., accessed March 7, 2007. The term "supleanter" or "vararerepresentant" meant that Bonde and Bauge were substitutes for the elected representative if he was unable to be present. 
third largest party in the Storting and its representative on the Committee was Erling Bjørnson, a farmer from Opland County, one of 21 representatives and 7 substitutes. Carl Emil Christian Bonnevie (1881-1972), who was a rural magistrate from Lofoten as well as an Ap representative from Nordland District, was the third member of the committee. ${ }^{612}$ The final member of the Committee was a state's attorney, Olaf Fjalstad, a Conservative representative also from Nordland County. He was first elected to the Storting in 1928 and would remain in that seat until occupation and afterwards until 1945. While representing this county he was also the Mayor of Tromsø in 1927 and a member of that city council from $1923-1937 .^{613}$

The Society Party (SP) was a very small party, organized by Brochmann in the early 1930s; the party disbanded itself in 1940 with Nazi Germany's occupation of Norway. Brochmann began his career by creating The Free Society Press ${ }^{614}$ in 1929 and the newspaper Samfundsliv (Societal Life) ${ }^{615}$ in 1931 and finally, organized the Society Party in 1933. There was little structure to the party and this gave Brochmann great latitude in the formation of policy. While in the Storting, he refused his salary saying he did not want to be a "parasite" 616 on society. But Farmers' Party member Bjørnson also used the word "parasite” in this debate since it referenced Brochmann's SP philosophy. The debate itself has been translated from the original and can be found at Appendix E. ${ }^{617}$ Despite his refusal of a salary, Brochmann later aligned himself with the economic policies of the Quisling government and, after the war, was convicted of treason. The last time a Society Party member stood for election in Norway was in 1949. Robert Lalla describes Brochmann's ideas as a "a combination of Christianity and depth psychology." ${ }^{18}$ In 1936, Bonde himself described Brochmann's economic politics as a "total economy”, one in which the

612 I have interpreted the Norwegian word "fylke" as "district." Bonnevie was "egnens stortingsrepresentant" from 1934 to 1936. Please see, http://no.widkipedia.org/w/index.php?title=Carl_Emil_ Christian_Bonnivie\&printable $=. .$. , accessed June 20, 2009. He was also stationed as part of the Norwegian legation in Berlin and Vienna from 1919-1923.

613 Ibid., 183. The composition of the 1934-1936 Storting can be seen at Appendix D with regard to party composition and livlihood.

614 Det Frie Samfunds Forlag.

615 Sanfundsliv.

616 "Snylte" in Norwegian.

617 The word "parasite" was also in circulation in both race-hygiene materials as well as in the Samfundpartiet rhetoric. The most that can be said is that Bjørnson may have used the word in his opening remarks as an intentional brace thrown at the feet of Bonde.

618 Robert Lalla, "Henimot nullpris! Samfundspartiet økonomiske tanker” in Diskusjonsnotat \#D11/2004, p. 4 at http://www.umb.no/ios/Publiskasjoner/d2004/d2004-11.pdf, accessed December 7, 2007. “...en blanding av kristendom og dybdepsykologi." The term "depth psychology” was coined by Swiss psychiatrist Eugen Bleuler (1857-1939) and, today, refers to a combination of theories and therapies usually attributed to Sigmund Freud, Carl Gustav Jung and William James. 
most important elements were “...decapitalization, a national accounting [system] and decentralization." 619

S.R. Bjørnson (B) started his comments by proudly endorsing the sterilization bill. Saying that it "fell to a farmer" who understood the workings of nature to speak first in advancement of the bill, Bjørnson was enthusiastic about all things scientific. Science and the will of the people, striding "hand in hand", had increased the average life expectancy of Norwegians. If this was to continue, then "powerful, genetically sound and productive stock" had to be produced, and "parasites" had to be eliminated just as weeds on farm had to be eliminated. However, those in society who were "capable workers" had, he argued, been "saddled" with a broad range of taxes and fees since, by 1934 , it was no longer a matter of being "disgraced" if one went on welfare. This was a situation that made the capable, productive workers lose their own "will to live."

Bjørnson did mention the German forced sterilization law, but only in passing. He mentioned that the then-current German government took the condition of future generations so seriously that it disbursed "hundreds of millions of kroner" to help "new marriages." But he moved on rather quickly to say that future generations of Norwegians might well criticize the Storting later for not acting sooner and in a more fundamental manner. He also argued that the law "also gives an opening to go a bit further and open for admission to forced sterilization... [to other persons]." ${ }^{620}$ I think it is fair to conclude from this that Bjørson probably hoped that this law would be only a first step towards a more comprehensive law since he added, if a such a bill were to be introduced, he would vote for it. Then, Bjørnson analyzed the strategy of why the bill was not as far-reaching as "we" would have liked. It was written as it was for fear that, if broadened, it would not be acceptable to the Lagting in much the same way as the recently failed law on women priests was not acceptable, a measure which he had also supported. Bjørnson was a man who clearly considered himself as a "progressive", supporting both the sterilization law and the law allowing women to become priests in the state Church. Bjørnson ended his remarks by thanking Minister Sunde for the "splendid" bill and the Norwegian Advisory Committee for Race-Hygiene and its "indefatigable leader”, Dr. Alf Mjøen, who might at that point - finally - receive the recognition in Norway that he had achieved in other nations.

Representative Bonde was the next to speaker and called the bill "...on the whole, one of the most dangerous proposals that has seen the light of day." ${ }^{621}$ From his remarks we know that Bonde believed that the law would obviously - and was intended - be extended to include "sexual criminals", a term never really defined by

619 Ibid. See also, Gjert Edvard Bonde, 3rd ed.Totalitetsøkonomi: En oversikt over Samfundspartiets ideologi og retningslinear (Bergen, 1966).

620 Appendix E.

621 Appendix E. 
anyone in the Committee, thus raising the specter of homosexuals grouped together with pedophiles and sexually violent persons. Bonde's argument, as we will see, was one that has not changed much over the time span of these two cases. His opinion clearly favored "nurture" as opposed to "nature" since it was "societal influences" that he believed were the cause of crime. Bonde brought powerful themes to his remarks and used religion, saying that the Storting had not learned its catechism lessons and was "casting stones" just as in the Bible parable. He also accused the bill of being "barbaric and medieval" in its functioning, i.e. letting the innocent suffer for the sins of the guilty since it would be criminals who would suffer for the failure of society to change itself. Calling to mind more "modern" lines of argument, he said that if one wanted to be absolutely sure to create criminals, then jail was the place to do this. Finally, he challenged the Committee to consider the "new science" of psychoanalysis as a substitute measure for actual sterilization in the case of criminals.

Committee member Judge Bonnevie calmly rejected all of Bonde's arguments, saying Bonde had "missed the mark" in his argumentation, i.e. that the bill was not intended to sterilize "this third group", i.e. criminals. Where Bonde relied on religion in argumentation, Bonnevie instead spoke of political theory when he argued that the "right[s] of the individual must be weighed against the right[s] of society...." 622 But Bonnevie also thought that he and like-minded supporters of the bill had achieved " a deeper insight both into the interests of society and a deeper feeling of responsibility for generations to come." 623 What he meant by this deeper insight is unclear. In closing, he made sure to distance what the Committee was doing from anything that had happened in Germany, saying that whatever Germany had done was neither "partly" nor "totally" of any consequence in the Norwegian debate. In Bonnevie's mind, the prepatory work on the bill done by other Scandinavian countries as well as work done by Dr. Johann Scharffenberg was of more importance.

At that point in the discussions, Bonde handed a motion to the President that the 1934 Odelsting not consider the bill during that Session. Representative Fjalstad (H), a second-tier player in the debate, spoke next and merely echoed the importance of the consent provisions in the bill, echoing what both Bjørnson and Bonnevie had said. Cabinet Minister Sunde then spoke, essentially taking the debate in another direction in what amounted to an ad hominum attack on Bonde. Minister Sunde said “...before a person uses such types of expressions, he should take the trouble to read the bill and preferably, the entire preparatory work." ${ }^{624}$ In other words, Bonde's competence as a diligent and careful representative was, at that point, on the table in much the same way as the bill itself.

622 Appendix E.

623 Ibid.

624 Ibid. 
Bonde spoke accusing Bonnevie of claiming the same opinions that he, Bonde, was defending saying this was "typical" for Bonnevie. Bonde railed, as much as one could "rail" in about 15 minutes of debate, against the "system" in the Storting that allowed only for the "party opinion" and nothing beyond it. The fact that Bonde represented an entire party, the Society Party, was of no moment, or so he said. Other "scientific" work, at odds with the need for sterilization of criminals, was well known throughout the world and none of this had been taken into consideration in the preparation of the bill. Bonde challenged Sunde to deny this.

Bjørnson then spoke, taking his cue from Sunde, and advancing Sunde's accusation that Bonde had not even read the bill, much less the preparatory work. However, the Storting debate was conducted in 1934 and whatever the written and unwritten rules of conduct were, Bonde was accused of an "attack" on the Committee. ${ }^{625}$ Bjørnson simply reiterated previous arguments, but also mentioned the birth rate in Denmark where "healthy...responsible families" were not having children while "defective families" were; this appears as a typical "race suicide" argument, reminiscent of the same arguments in Indiana in 1907. By his remarks, we can see that Bjørnson was quite involved in the passage of the bill. This stemmed, at least in part, from the fact that he and Bonde had crossed swords before since, since Bjørnson said, "this is not the first time that I have fought against this reactionary line." ${ }^{" 26}$ Bjørnson ended by saying that the Society Party advanced "a type of freedom that the rest of us do not understand." 627

Bonnevie spoke for the last time, again accusing Bonde of not reading the documents associated with the bill. And it is here that we find that other, unprinted documents had been read by the Committee that were not included in the record of the Storting; Bonnevie says that if Bonde had read everything, "and, in addition, more of the unprinted documents", Bonde would have seen the necessity for the law. ${ }^{628}$ Exactly where these "unprinted" documents came from was not mentioned. However, given the nature of the debate, I suspect they were most likely from Professor Ragnar Vogt, Medical Director Scharffenberg and others, as well as Dr. Alf Mjøen.

Bonde's last remarks were directed at countering the accusation that he had not read the bill. He asserted that he has read the documents and said, "I treat this matter quite simply from the spirit of the law and the meaning that lies in the law and which will lead to the castration of sexual criminals as one of its goals." ${ }^{629}$ Calling the law a "brutal" and a "violent" intrusion on the individual, Bonde ended by saying that

625 Appendix E.

626 Appendix E.

627 Appendix E.

628 Ibid.

629 Appendix E. 
the branch of psychology that Vogt and Scharffenberg represented had nothing to do with the science he had in mind.

Finally, a vote was taken on Bonde's attempt to postpone the bill and this was defeated. A second vote was taken on the law, with one vote against it. After a suggestion from the President, a unanimous vote was taken agreeing to send it to the Lagting. ${ }^{630}$

These 10-15 minutes of Norwegian parliamentary history are informed by a number of values/norms and normative processes discussed in Chapter 2. If we apply Tamanaha's model, then we must examine the social norms and societies from which the law originated. The use of the words and phrases such as "parasite”, "capable workers", "innocent suffer for the sins of the guilty" and "brutal and violent intrusion" in rhetoric taps into a very powerful epistemic level, a resting place for such norms/values sometimes espoused during moral panic and epistemic uncertainty.

\subsection{Reactions to the Norwegian Sterilization Law}

In 1938, Harald Bjelke issued a directive from Oslo regarding the "supervision" and "treatment" of sterilization cases. ${ }^{631}$ It sought to clarify various situations and was incorporated by reference into the Norwegian sterilization legislation. It also added sections such as the fact that permission would no longer be needed if the medical reasons for the operation were themselves lawful. ${ }^{632}$ Although the 1934 law was modified after its passage, the biggest changes were yet to come after Nazi occupation.

German forces entered Norway on 9 April 1940 and completed their occupation approximately one month later, on 8 May 1940. The Storting was disbanded and instead, a "Riksting" was set in motion as a law-making institution. The Nasjonal Samling (NS) government also instituted a leadership role for a person whom they considered had natural leadership capabilities, i.e. Vidkun Quisling, and set about to administer the nation. Since the normal prepatory work usually done in advance of the passage of a law was not done after this, preparation was "correspondingly reduced, both in quantity and content." ${ }^{633}$ The Justice Minister during the Nazi

630 Appendix E. Those who were appointed to the Sterilization Advisary Committee under paragraph 2 included Medical Director Heitman who was the "Chairman”, prof. Ingebrigtsen, prof. Ragnar Vogt, Supreme Court judge J. Rivertz and dr. Nic. Hoel.” (Aftenposten (a.m. Edition), July 27, 1934, 2.) 631 Haave, Sterilisering av tatere, 1934-1977, 394. Note 510. "Veiledning i behandling av steriliseringssaker."

632 Ibid. Paragraph 2.

633 Henriette Sinding Aasen, Rasehygiene og menneskeverd (Oslo: Insititutt for offentlig rettskriftserie nr. 4, Kvinnerettslige studier nr. 28 (A), 1989), 5. 
occupation of Norway was Sverre Riisnæs ${ }^{634}$ and the Medical Director was Thorleif Østrem. ${ }^{635}$

The "Lov nr. 1 til vern om folkeætten av 23 juli 1942 med tilhørende forskrifter av 1 oktober 1943" (hereafter, "Protection Law of 23 July 1942") held that any person who had a "genetic sickness or defective condition" could be forcibly sterilized. ${ }^{636}$ The point of the legislation was to prevent persons with "bad" ${ }^{37}$ genetic material from reproducing. Briefly, the changes expanded the ways in which the 1934 law could apply to a person. $\S 13$ annulled the 1 June 1934 law on sterilization. $\S 8$ changed the composition and size of the 1934 law’s Advisory Committee under its $\S 2$. Whereas previously the Committee had 4 members in addition to the Medical Director as Chair - 1 woman, 1 Judge and 2 medical doctors - the committee would, in 1942, consist of 6 members named by the Ministry of the Interior and was composed of 2 doctors, 1 eugenicist, 1 Judge and 1 woman with the Committee empowered to elect the Chair. ${ }^{638} \S 5$ allowed suggestions for whom to be sterilized. These could be put forward by a doctor, the head of a prison, force work institution, school, hospital, or reformatory. ${ }^{639}$ In addition, the Police Chief, the Welfare Board, the Guardianship Committee or the Sobriety Committee of the place where the person lived or was currently located could also make the recommendation. ${ }^{640}$ Finally, what Representative Bonde had feared during the Storting debate of 1934 eventually became a reality. §3 allowed removal of the desire to reproduce if the individual was found guilty of a crime under Chapter 19 of the Criminal Code and it was presumed that this conviction was the result of an "abnormal" sex urge. Forcible sterilization could also take place if the person was mentally ill, developmentally delayed, had permanently impaired mental faculties or there was a danger that the person would commit some crime under Chapter 19 of the Criminal Code.

The regulations enacted on 1 October 1943 ennumerated the types of hereditary conditions that were presumed to be included in the 1942 law. These included mental illness, and "developmental disability", "serious" forms of psychopathy including antisocial individuals, "serious” forms of alcoholism, schizophrenia, epilepsy, St. Vitus Dance, blindness, deafness, "serious” forms of bodily malformation. What was actually in this list was, however, almost inconsequential since it also included a

634 It would be interesting to know if this man Riisnæs was the same policeman who testified at the Mrs. Tilka hearing. Both the Mrs. Tilka and Mrs. Aagot Hansen cases are mentioned below.

635 Appendix E, §2

636 Ibid.

$637{ }^{638}$ Haave, Sterilisering av tatere, 1934-1977, p. 394. Note 510. "Veiledning i behandling av steriliseringssaker."

638 Ibid.

639 Ibid.

640 Ibid. 
catchall phrase whereby all serious forms of other sickness or defective conditions that were not mentioned could be a basis for inclusion under the 1942 law.

After the Nazi occupation, the law of 1 June 1934 law was again in full force and effect in Norway. It wasn't until 1950 that then Medical Director Karl Evang added another directive to the use of the sterilization law. ${ }^{641}$ Certain IQ requirements were set in place and three types of situations were discussed. If a person was between 9 and 12 years old and had an IQ of 56-75, then this was "often" seen as a case of developmental disability, especially when combined with some psychological problem. ${ }^{642}$ If the same person had an IQ of 75-90, s/he was presumed to be "normal" so long as there was no psychopathology or mental illness that complicated the matter.

Finally, forty-three years later, on 3 June 1977, a new law was passed that replaced the 1 juni 1934 sterilization law. The new law (3 juni. Nr. 57, 1977 Lov om sterillisering) provided for sterilization or castration of a person living in Norway if the person was 25 years and applied for permission for it to take place. ${ }^{643}$ The medical indications used to set the law in motion were limited and it was not applicable to cases of "medical or other reasons" for the operation. Furthermore, the law was not seen as commonly applicable to persons with serious mental problems or to the developmentally delayed or to psychological impairment. ${ }^{644}$

Henriette Sinding Aasen has made an evaluation of the 1934 law in light of the changes made later in 1942. She found that in the prepatory work of the 1934 law, there was contact with German authorities regarding the Norwegian sterilization legislation. ${ }^{645}$

Among other things that were said about the German sterilization law of 1933 was that it was "alleged" to have been used as a pattern before the decision in the Committee's proposed bill was drafted. (Medisinalavdeligen 1941, s.5) (46 $^{64}$

Her final evaluation of the two laws is very interesting. After having studied both laws and the entire racial hygiene debate in Norway prior to World War II, she says that

641 Ibid.

642 Ibid.

643 Hans Flock and Birger Stuevold Lassen, Henrik Bull, Anne-Marie Tronslin (eds.), Norges Lover 1687-2003 (Oslo: Det Juridiske Fakultet at the University of Oslo, Hos Glyldendal Akademisk, 2004), 1073.

644 Ibid. §2 "Dette gjelder ikke person som har en alvorlig sinnslidelse eller en psykisk utviklingshemmet eller psykisk svekket.” This phrase however, is footnoted with reference to Jfr. §3. "Lovens område" is translated as "jurisdiction."

645 Aasen, Rasehygiene og menneskeverd, 55. Note 820.

$646 \mathrm{Ibid}$. Blant annet ble det sagt at den tyske steriliserings-lov av 1933 "formentlig” hadde tjent som forbillde for vises bestemmelse i komitéens forslag. 
I am left with the image of a long process starting with medical and biological research, that built up towards the insane climax represented by National Socialism. Throughout, the goal all along was to change the fact that even "lesser" individuals, people with symptoms of deviance, were part of society as a whole. ${ }^{647}$

Consequently, she asserts that there was no "fundamental" separation between the 1934 law and the 1942 law in how those in control viewed society, whether or not the basis for the implementation and reinforcement of them was different. ${ }^{648}$

Representations of what good science could produce were combined with legal representations in an on-going process that was reflected in the laws themselves. The sterilization law of 1934 was preceded by a great deal of work by numerous people in Norway and it did not appear from nowhere. The representation by science that it could promise "progress" was both implicit and explicit. This provided yet another untested assumptive articulation with the law. If science could produce "progress" in a socially and politically unstable time for the majority of people in the country, then one could assume that the always-delicate balance between individual and societal rights and duties might also shift.

One problem with previous evaluations of the eugenics movement and its legal manifestations has been to assume that it was confined to a time period before and during World War II. However, some of these laws remained in effect, for example quietly sterilizing people that were not so obviously "defective" and usually due to their body status, i.e. female, poor and/or non-white. This is seen in both the American and Norwegian halves of Case One. The number of women who were sterilized continued to increase after World War II in both countries. ${ }^{649}$

\subsection{Jasanoff Fields Reflected in the Norwegian Media}

On Monday 8 January 1934 Aftenposten produced a large article on Gregor Mendel (1822-1884) entitled "The Founder of Genetics Research - Gregor Mendel." 650 Since the Austrian monk Mendel was born on July 20 (or 22), 1822 and died in January 1884, the article was meant to coincide with the anniversary of Mendel's death. Written by Fridthøf Økland, the article goes in predictable directions describing Mendel's work and its importance for science and society in 1934. However, two interesting uses of language did appear. First, is that Økland uses the word "tragedy" to refer to the

647 Ibid., 62.

648 Ibid., 62-63.

649 Carey, "Gender and Compulsory Sterilization, 74-105. Note 2008.

650 Aftenposten (a.m. Edition), January 8, 1934, 8. Norwegian newspapers of all political orientations did, on occasion, carry "educational" articles. Arbeiderbladet would normally do this in their Saturday afternoon edition while Aftenposten might do it at any time but more normally in the morning edition. 
fact the laws of genetics were not discovered sooner. Second, it was also a "tragedy", according to Økland, that Darwin was unaware of Mendel's work since, if Darwin had been aware of that body of work, the history of Biology would have been written differently. In addition to the announcement of the new German Race Hygiene Law on 2 January and this article, we can see that within the first 8 days of newspaper production in 1934, all the elements of competing discourses and values/norms were already in place, ready to be played out over the next period to time.

Normatively inspired representations of what human sexuality meant took place in Norwegian newspapers in 1934. Dr. phil. Richard Eriksen wrote a feature article entitled "Sexual Fears" on 25 August. ${ }^{651}$ He began his editorial admitting that sexual information in society was necessary. However, "the sexual problem" could not be solved with information alone. What this "sexual problem" actually was remained undefined and only insinuated but one possibility is that it may have focused on masturbation, just as that also was a major reason for sterilization according to Indiana's Dr. Sharp. According to Eriksen, the problem was so interwoven into the personal, social, cultural and religious life of society that physiological and hygienic knowledge alone would not be adequate to solve it. Eriksen wrote in his editorial against what he considered one of the fallacious arguments against sexual abstinence that was circulating at that time. The argument was that the male sexual organs needed to be emptied from time to time just as the urine bladder was emptied and that not to do this was unhealthy. Setting one's urges free as psychoanalysis suggested was also no solution according to Eriksen, who mentioned Jung, Adler and Freud and the fact that he was uncomfortable with their work. ${ }^{652}$

Also in August, Lektor Harald Amundsen wrote a feature article entitled "The Feminine Direction in the 'New' Genetics." ${ }^{53}$ Amundsen cited to author Adolph Matthias of Germany on the discovery of the sex-linked XY chromosome concept, the Y from the father and the $\mathrm{X}$ from the mother, which, when united, produced a male

651 Aftenposten (a.m. Edition), August 25, 1934, 2. This type of article was a regular in Aftenposten. I use the term "feature article" for what is the norwegian word "kronikk" which is a submitted op-ed piece. It is not the quivalent of an editorial; it was a solicited piece or one sent by a professional in the community for inclusion in the newspaper. It was usually a political or scientific-educational article, located at the bottom of the second page.

652 Ibid. A Richard Eriksen defended his PhD dissertation in Christiania in December of 1915. The thesis was entitled "The Psychological Basis of Thinking” "“Tænkningens psykologiske utviklingsbetingelser") Eriksen's disapproval of “modern” psychology, in combination with Bonde's comments in the Storting Justice Committee meeting, indicates a split of opinion within the scientific and political communities on the worth of psychiatry, a split possibly by one's party affiliation. We find a repeat of this issue in the 1970s with the issue of treatment for a young girl supposedly possessed by the devil. Should the Church or a psychiatrist treat her?

653 "Den feminineretning i den 'nye' opdragelse" Aftenposten (a.m. Edition), August 1, 1934, 2. The title "Lektor" is used for the highest teaching position in secondary schools and for some positions at the university level. 
offspring (XY). ${ }^{654}$ Amundsen was not pleased with this development, whether based in accurate scientific research or not, since "this double-influence" had made its mark in both school and at home in Norway. He said that the "womanly element has become over-balanced." ${ }^{655}$ He complains of Fru Stang from the Norwegian Feminist Association, saying "Before fru Stang and modern psychology gave us an explanation, we didn't know how the reduction in the number of children - all children has now come to be.” Amundsen also cited to Adalbert Czerny (1863-1941), a Berlin medical doctor, who was prominent in the specialization of what is now known as pediatrics but one sentence in particular leaves little doubt as to the political - rather than scientific - nature of his editorial. He says:

What is needed now is resolute action against the destructive activity of the last generation if the mind of the nation is not to be destroyed.

Whatever Amundsen perceived the influence of the feminine and of psychology on children to be, it was to him a most serious matter. His first editorial was continued the next day when he cited to educational psychologist Henri Bouchet complaining that there is a "real individualism" and a "false individualism", the latter leading to "egoism" and a "lack of discipline." 656

In this brief compilation of science-related articles that circulated in the media in Norway 1934, we see that the representations from experts ranged from what we now view as absurd to articles that now seem standard or even about the cutting edge of science work on genetics. But we should remember that, to the persons living at the time, it might have been "absurd" that the physical sex of an individual was determined by chromosomal input from both the male and the female. Only since 1934 has this been accepted as good science. It was good science in 1934 too, except that Amundson's interpretation of it politicized the scientific fact. Otto Mohr feared “objective” scientists entering into problems “not strictly scientific”, and Amundson's article demonstrates how Mohr's fear could be played out in society. ${ }^{657}$

In this society and this time, what type of treatment could a person with no money or influence expect to be treated? I present two examples here - one "Tilka" and Aagot Hansen.

\section{Ibid.}

655 Ibid.

656 It is difficult for a non-Norwegian to understand the meaning and importance of this charge of "egoism." At this time especially, but even today, the word is used to mean something more than simply being self-centered.

657 Library of Congress (Washington, D.C., U.S.A.), Papers of Margaret Sanger, Accession Number 16,700, Vol. 29 Reel 19. Letter dated 11 May 1926. Letter dated Oslo, 8/11, 1927 by Otto Mohr, end page two and begin page three. 
Unemployment and homelessness in Oslo presented a problem and the actions of those that were charged with keeping order articulated with both the medical and legal institutions. And, as I will point out, neither of these institutions could be counted on to resist non-normative behavior, thus unwittingly adding to the categories of people who could be forcibly sterilized. This was seen in the judicial machinations surrounding two women - Aagot Hansen and Tilka. The equivalent articulation occurred in the United States in the Henry Thaw case although the precipitating factors were different.

Of these two cases, the Tilka case is the easier to summarize. She had stolen a pair of pajamas and Officer Riisnæs testified against her, despite the fact that her competence was clearly an open question. On 3 January 1934 Aftenposten reported that Judge Juelsrud had refused to jail Tilka for lack of evidence. ${ }^{658}$ Tilka was put on a stool before him and the Court tried to take testimony from her. Her defense attorney was playwright and defense attorney Vilhelm Dybwad (1863-1950). The ultimate goal of the hearing was to decide if she should be forced to undergo a psychiatric observation. What was known was that she was 60 years old and had been born in Danzig. As the newspaper reported, she appeared nervous and "broken." Her testimony was "unclear" and her memory was "very bad." She did not remember how many children she had or where she had been and when. From other testimony we learn that, between 3 June and 26 December 1933, she had been "disorderly" and had finally been jailed under Criminal Law $\$ 148$ and $§ 257$ for stealing some pajamas. Police Officer Riisnæs ${ }^{659}$ testified that she had also served 40 days some sixteen years earlier for shoplifting. No decision was made and the entire matter was revisited in the newspaper throughout 1934 . Here we have the intersubjective category of gender implicated along with the facts for being older, poor and from another country.

The articulations in Tilka's case were standard but Aagot Hansen's case is notable because she had spent a number of years confined in a mental institution - without actually being mentally ill. Headlines from Aftenposten on 16 January declared that there were "strong" allegations of misconduct against the doctor involved in that case. Hansen had as her attorney, a Mr. Fuglesang, who was on that day in the process of taking the testimony in court from Hansen's doctor, also named Hansen. ${ }^{660}$ According to Fuglesang, the doctor had shown "gross inattention" to the patient and her situation. ${ }^{661}$ We read of Attorney Fuglesang's accusation and yet, the state's doctor, Dr. Hansen, had provided for the Court a lengthy document outlining his compliance with all the pertinent rules and regulations. Fuglesang's retort was reported as "dramatic" and to the effect that if the state-employed doctor had only used the printed

658 Aftenposten (a.m. Edition), januar 3, 1934, 1, continuing to 2.

659 Riisnås is only identified as "politifullmektig”, i.e. assistant Chief of Police or Desk Sargeant.

660 Aftenposten (p.m. Edition), January 16, 1934, 1.

661 Ibid. 
form, then he might not have had "enough space to write his (numerous) erroneous notations." ${ }^{662}$ Was Aagot Hansen merely a petty, female troublemaker who must be mentally defective since she did not fit into the normative social structures held by the medical and legal institutions of that time and place?

Dr. Hansen was eventually charged with unlawful detention of Aagot Hansen under Criminal Law §226. Claims were brought against him not only for damages done to Aagot Hansen but also for the costs of Fuglesang's work. Fuglesang also examined the Director of the Lier Asylum, Dr. Christian Grimsgaard (1868-1939). Fuglesang emphasized that Grimsgaard should have refused to admit Hansen from the start after an examination of the papers which accompanied her to the asylum. Using a phrase that has become a classic in American tort law, Fuglesang said that Grimsgaard "should have known" by looking at the papers that she was not to be admitted. Fuglesang quoted from the State Attorney's brief that essentially admitted that Grimsgaard should have released Aagot Hansen, especially since both Professor Ragnar Vogt and Doctor Evensen had not found her to be mentally ill. ${ }^{663}$

Aagot Hansen testified as to the details of her handling at the Lier Asylum but there is not a great deal of this testimony in the newspaper. However, Fuglesang produced the initial observation of Aagot Hansen's presenting characteristics as "frigid, and with feelings of inadequacy." 664 Within the presence of the patient, Grimsgaard was reported to have said, "One gets all types of folks here." When trying to substantiate this and other facts, Fuglesang was denied a meeting with the workers and nurses at the Lier Asylum. He also reminded the Court that the Mental Health Asylum Control Commission required the patient to be examined within 7 days of admittance and, if this had been done, it would have been obvious that she was not mentally ill. ${ }^{665}$ As the reporter noted when ending the article, absolutely nothing had been said to discredit Aagot Hansen's behavior. And, at that point, the case had only begun.

On 3 February, newspaper reporting of the case continued. ${ }^{666}$ Fuglesang's adversary was statsadvokat Jak E. Anderssen (b. 1882). The use of Anderssen in this case is interesting since Anderssen had been an Assistant Chief of Police in Oslo for many years and according to Aftenposten "had a great concern for cases involving the mentally ill." ${ }^{667}$ In fact, he had written a handbook for their treatment in 1921. Anderssen argued that, since Police Chief Bang's choice had been to put Hansen in administra-

$662 \mathrm{Ibid}$. From these newspaper accounts, Fuglesang appears to have been a seasoned attorney and knew how to use a moment in the courtroom to his advantage. It was clearly one of those "dramatic" moments when he addressed the state's witness Dr. Hansen and asked - rhetorically - if if he would have had enough space to write everything about the case if he'd used the required form.

663 Ibid.

664 What these two indications have to do with mental illness is unstated.

665 Aftenposten (p.m. Edition), January 16, 1934, 1.

666 Aftenposten (a.m. Edition), February 3, 1934, 5.

667 Ibid. 
tive observation, a choice he could make, her detention was completely lawful. In that sense, her detention was more "considerate" than the issuance of a Commitment Order to Prison. ${ }^{668}$ When Officer Riisnæs testified at the Tilka hearing, it probably also had something to do with the number of unemployed out on the streets of Oslo rather than simply dealing with a "disorderly" older woman. One way for the Oslo police to cope could have been to use other institutions such as those for the "insane" to deal with the problem of overcrowding in the Oslo jail; this also made these people someone else's financial problem.

A number of legal questions were addressed during the hearing. The question arose whether or not a declaration of observation had been written. There had been interference with a citizen's liberty; this would have been the best method to use in order to avoid criticism. The newspaper commented, "It appears, nevertheless, that no place is it written that the observation document should be written and that this form can obviously in simple cases be ignored." ${ }^{669}$ Should Chief of Police Bang have demanded a court order to take Aagot Hansen into custody at the hospital? The state's attorney answered in the negative saying that many cases were handled in Oslo which could, in fact, have been prosecuted as criminal cases but which were handled as an administrative matter. He gave the example of a man who had begun firing his rifle in his house and the occupants reported that they had been concerned for his mental health; this case had been handled administratively rather than criminally.

Fuglesang asked if, in another case where a man had shot the rifle, was it reported to the police? The answer was "No" but with regard to the Aagot Hansen case, Bang had a police report to consider and which he depended upon to become involved in the case. How one decided to become involved Bang said, "It [the decision] must be based on [the] discernment/understanding [of the authorities]." ${ }^{670}$ But Fuglesang was not deterred. He asked, "On the Police Chief's discernment alone?" The witness answered, "It could be. It depends on the situation and circumstances." 671

In response, the state's attorney had the witness testify that a policeman did not have the psychological insight needed to appraise the detainee's mental condition, that only a qualified doctor could do so. The witness said it was impossible to have a working knowledge of everyone and that one had to rely on reports given by people who knew the unruly - and possible ill - person. If there was a sense of urgency, one could rely on the police doctor for an observation as to the detainee's mental condition. ${ }^{672}$

668 Ibid.

669 Ibid.

670 Ibid.

671 Ibid.

672 Ibid. 
Fuglesang continued and suggested that not out of respect to Aagot Hansen herself but out of respect for the larger municipality where Lier was located, shouldn't the judicial path have been chosen? The witness answered that one couldn't really say that it was a mistake to have chosen the administrative solution. He did not know if the doctor's information resulted in the request for admission to the asylum but the state's attorney statements were enough since there actually were numerous documents, which the Chief of Police had no need to see, and should rather be in a closed envelope. There was a form for this type of information, but it wasn't necessary to use it. All the information could have been written on another paper. Fuglesang asked the witness if there were forms available and the witness answered that the police station as "full up" with them.

Later, in the courtroom, the Administrator posed a question to which the state's attorney explained that, when a mental illness declaration was not done, such as was the case at the with Aagot Hansen, then a dangerousness declaration should be requested and that this could be grounds for admission to the asylum even if the patient was later found not to be dangerous. The state's attorney also said he would have, in retrospect, followed the same course of action in conjunction with the decisions taken by Chief of Police Bang. When one was concerned with presumably mentally ill persons, the most appropriate choice was the administrative choice, out of respect to the people involved. ${ }^{673}$

Professor Ragnar Vogt was present and asked the state's attorney a question about "dangerousness." Vogt took the opportunity to comment that, in his experience, dangerousness was less of a concern and was unnecessary for an administrative detention in an asylum. In response to another question the state's attorney reiterated that Aagot Hansen did not have some sort of sentence to do and her detention was not to be characterized as an arrest. The assumption was that a mentally ill person was being taken in for safekeeping. The last witness was the Ward Nurse from Lier Asylum, Agnes Berge. She testified that Aagot Hansen was difficult to deal with the entire time she had been at Lier. Aagot Hansen was not satisfied with the food and often swore. At that point, the case was adjourned and would be continued at a later date.

While this may seem like a diversion from my discussion of Norway's sterilization law it is here to show that a woman, a petty thief at most, who had been admitted to an insane asylum, even though not insane, could have been forcibly sterilized. Neither the institutions of medicine nor law could have been relied upon to review her situation. While in the institution, the only thing a nurse had to say about her was that she cursed and didn't like the food. With the passage of the new sterilization law, a new category of persons - vagrants - was included under it, whether admitted or not. Also, whether or not the Autonomy Theory of Law (AT), a philosophical device

673 Ibid. 
that seeks to separate social norms from legal norms existed was of no moment in the life of Aagot Hansen. ${ }^{674}$

As I wrote at the end of the first half of Case One (Indiana 1907), Jasanoff's model of co-production allows an evaluation of how the Indiana sterilization law was enacted. The same model can be applied to the Norwegian sterilization law of 1934. As I pointed out at the end of the section dealing with Indiana, both science and the law created representations - in response to other social representations - of what was "defective", of what was "sane" or "insane" and of what was the "normal" manner of being a woman. As Henriette Sinding Aasen writes, quoting NS jurist Per Melsom, that "the [legal principle] rested on the biological "demand" which then formed the right to sterilize, and this was that

the fundamental idea that the National Socialist right to develop rests upon, is biology. This right should serve life....The right has no goal in itself but it is at the center of a people's right to be secure in their life and development. ${ }^{675}$

Aasen writes that this must be regarded as "a new 'tradition' in Norwegian jurisprudence and legal philosophy." Aasen notes that the beginning point for any legal rules was no longer the "need to give the individual her rights and duties in a society ruled by norms and the division of authority." ${ }^{676}$ As Melson put it, the principle he advanced "was [designed] so that its usefulness to the people must be the decisive point in both theory and practice." ${ }^{677}$ While it may seem that I am over-stating the argument by the use of Melsom's words, it would be just as simple to argue using Representative Bjørnson's words. The point is the same; representations by both law and science dovetailed with overlapping schemas and structures to produce a law that, at a particular moment in history, chose the good of the group ("people") before that of the individual. The body became an epistemic index for the social stresses at work in Norway.

The legal and medical institutions, as both social structures and as a place for social networking articulated to help produce the sterilization law of 1934 as well as define the contours of sanity and insanity, what was acceptable and unacceptable for males and females, what was "normal" and not "normal." The law and science negotiations that were taking place in Norwegian society at this time provided "a site were social order and scientific knowledges [were] mutually constituted." ${ }^{\mathbf{2 7 8}}$ During

674 I will discuss this theory more fully in Chapter 7.

675 Aasen, Rasehygiene, 29. Note 820.

676 Ibid., 55.

677 Ibid., 29.

678 Gary Edmond, “The Law-Set: The Legal Scientific Production of Medical Propriety” in Science, Technology \& Human Values, 26 (2001): 191. 
the interwar period, not only knowledge about genetics, but also about psychology entered Norway and was processed in a dynamic and evolving manner.

We can see the impact of new scientific knowledge in the law in Norway in both the parliamentary and the judicial arenas, in the sterilization law and the Aagot Hansen case. Another way of seeing this process is what Gary Edmond calls the "seamless web' between scientific and nonscientific forms of knowledge and life." 679 Through the interactions in the legal settings of either a Storting Chamber or Judge Juelsrud's courtroom, a law-science hybrid is produced. This hybrid is a contingent artifact of the time, place and society. The hybrid, in turn, both draws on and reinforces " a range of normative behaviors, commitments, and relations." ${ }^{680}$ As Edmond points out, the life of these hybrids would be "compromised" if they were either evicted from their formal settings or the law were somehow changed to consistently reflect a social justice. Without the hybrids, the flow of reciprocal legitimation between the two spheres would be slowed to a trickle. ${ }^{681}$

Edmond has used the idea of a "law-set" to focus on controversies that involve this legal hybrid. The term "law-set" is taken directly from H.M. Collins' use of the term "core-set”, meaning "a range of scientists linked in a web of interests and associations, conceived as important to understand a particular controversy and its outcomes." ${ }^{682}$ The law-set has basically the same meaning but within the legal arena. While Edmond examines trial transcripts and does not extend his analysis to legislative or parliamentary hearings, I do. ${ }^{683}$ Members of the law-set "are linked in a legal web" where the goal is to decide a controversy, to provide closure. ${ }^{684}$ One difference between the law-set as defined by Edmond's and my extension of his idea is that his is usually backwards looking within the courtroom while mine could also be used to look forward.

In conclusion, if we look at the variables in this pair of comparative studies that compose Case One, and not simply at the Eugenics Movement, I believe that 1907 and 1934 might not have been the best of times to pass this type of legislation. In more

679 Ibid., 192.

680 Ibid.

681 Ibid., 193.

682 Ibid., 194. Please see further, H.M. Collins, "The place of the 'core-set' in modern science: Social contingency with methodological propriety in science" in History of Science, 18 (2001): 6 -19.

683 My experience as an intern with the Washington State Legislature demonstrated that hearings prior to passage of any legislation were not only a venue for the staking out of normative positions but also a place where staff lawyers voiced their concerns about the legislation as written. For example, what would the "standard of proof" be in a new law? For this, one had to be conversant in previous case law and lawyers were routinely called upon for written materials prior to hearings. Politicians who cater to various constituencies rather than thinking about "the common good" often ignore these materials.

684 Edmond, Law-Set, 194. Note 866. 
modern times, proactive closure on certain bio-medical proposals in the legislature or the parliament might be indicated for a period of time. This would make sense since the same "law set" or, or "core-set" if you will, is involved.

Lawyers, police, scientist, judges and lay people converge to produce legally sanctioned outcomes designed to support their various and invariably competing interests and social visions. ${ }^{685}$

In fact, one could argue that the new "epistemic" hybrids that are produced in the legislative/parliamentary arena need to be examined even more closely than "Findings of Fact" from a courtroom at the appellate level. But this discussion also implicates the form that democracy now takes which is the subject of some other investigation, i.e. because a democratic society can legislate, should it legislate?

As I have shown, in both the American and Norwegian halves of Case One, the same intersubjective categories were implicated as subjects/objects of the new laws. The law-set in Norway in 1934 produced a sterilization law for "defectives", began work on amending the abortion law, and considered how to administer a process of admission to an insane asylum where "sane" people were not inadvertently locked up for months. The identities that were constructed in Norway and of which we see evidence of in 1934 are not very different at all from those we saw in the first half of this case in Indiana. The only obvious difference is the use of African Americans in Indiana and taterne in Norway, one a racial group and one an ethnic group. In both Indiana and Norway, these identities plus the identity of a person as "defective" by virtue of mental or physical disability were the main identities that were constructed on a daily basis. They were the "parasites" that cost Norway millions of dollars a year, in a time where that nation's economy was perceived as endangered and in which the majority perceived it as being in the middle of a political "crisis." These were the same type of people implicated in the Indiana law. The one consistent identity that we see as a type of bulwark against the demise of the population was that of "woman as mother." The point is, albeit in retrospect, that the population was not seriously endangered and that the role of women as mothers served as a smokescreen to reinforce comfortable, ages-old ideas of who and what a woman is and what she can and cannot do. 